\title{
0-0 bond formation mechanisms during the oxygen evolution reaction over synthetic molecular catalysts
}

\author{
Xue-Peng Zhang, Hong-Yan Wang, Haoquan Zheng, Wei Zhang, Rui Cao* \\ Key Laboratory of Applied Surface and Colloid Chemistry, Ministry of Education, School of Chemistry and Chemical Engineering, Shaanxi Normal \\ University, Xi'an 710119, Shaanxi, China
}

\section{A R T I C L E I N F O}

\section{Article history:}

Received 11 August 2020

Accepted 22 September 2020

Available online 5 April 2021

\section{Keywords:}

Oxygen evolution reaction

Water oxidation

0-0 bond formation

Transition metal complex

Molecular electrocatalysis

Reaction mechanism

\begin{abstract}
A B S T R A C T
Water oxidation is one of the most important reactions in natural and artificial energy conversion schemes. In nature, solar energy is converted to chemical energy via water oxidation at the oxygen-evolving center of photosystem II to generate dioxygen, protons, and electrons. In artificial energy schemes, water oxidation is one of the half reactions of water splitting, which is an appealing strategy for energy conversion via photocatalytic, electrocatalytic, or photoelectrocatalytic processes. Because it is thermodynamically unfavorable and kinetically slow, water oxidation is the bottleneck for achieving large-scale water splitting. Thus, developing highly efficient water oxidation catalysts has attracted the interests of researchers in the past decades. The formation of $\mathrm{O}-\mathrm{O}$ bonds is typically the rate-determining step of the water oxidation catalytic cycle. Therefore, better understanding this key step is critical for the rational design of more efficient catalysts. This review focuses on elucidating the evolution of metal-oxygen species during transition metal-catalyzed water oxidation, and more importantly, on discussing the feasible $\mathrm{O}-\mathrm{O}$ bond formation mechanisms during the oxygen evolution reaction over synthetic molecular catalysts.
\end{abstract}

(c) 2021, Dalian Institute of Chemical Physics, Chinese Academy of Sciences. Published by Elsevier B.V. All rights reserved.

\section{Introduction}

The rapidly increasing energy demands and environmental issues caused by the use of fossil fuels have been compelling scholars to find and use new, renewable, clean, and environmentally benign energy resources. In nature, solar energy is converted to chemical energy via photosynthesis, a reaction that occurs in green plants and other organisms [1]. During photosynthesis, $\mathrm{H}_{2} \mathrm{O}$ is first oxidized at the oxygen-evolving center of photosystem II (PSII) to release $\mathrm{O}_{2}$, which is essential for aerobic life. Moreover, the protons and electrons generated during the process are subsequently used to convert $\mathrm{CO}_{2}$ to carbohydrates, which sustain the life circle on Earth. Therefore, the oxygen evolution reaction (OER) is one of the most important reactions of the natural energy conversion cycle. The OER is initiated by the light-induced oxidation of chlorophyll P680, which presents magnesium porphyrin core structure, to form the porphyrin cation radical species $\mathrm{P} 680^{\circ}$. $\mathrm{P} 680^{\circ}+$ is the most oxidizing redox cofactor (redox potential $>1.0 \mathrm{~V}$ ) known in biology and provides the initial oxidizing power for the water oxidation reaction. The subsequent electron transfer from a $\mathrm{Mn}_{4} \mathrm{CaO}_{x}$ cluster of the oxygen-evolving center to $\mathrm{P} 680^{\circ}+$ recovers $\mathrm{P} 680$ and stores an oxidizing equivalent at the $\mathrm{Mn}_{4} \mathrm{CaO}_{x}$ cluster. After three successive turnovers, four oxidizing equiv-

\footnotetext{
* Corresponding author. E-mail: ruicao@snnu.edu.cn

This work was supported by the National Natural Science Foundation of China $(21101170,21573139,21773146)$, Fok Ying-Tong Education Foundation for Outstanding Young Teachers in University (by the Ministry of Education of China), Fundamental Research Funds for the Central Universities, and the Research Funds of Shaanxi Normal University.

DOI: 10.1016/S1872-2067(20)63681-6 | http://www.sciencedirect.com/journal/chinese-journal-of-catalysis | Chin. J. Catal., Vol. 42, No. 8, August 2021
} 
alents are stored at the $\mathrm{Mn}_{4} \mathrm{CaO}_{x}$ cluster, which triggers the formation of $\mathrm{O}-\mathrm{O}$ bonds via the coupling of a $\mathrm{Mn}(\mathrm{IV})$-oxyl radical and a di-Mn bridging oxo group [2-7]. Lastly, two $\mathrm{H}_{2} \mathrm{O}$ molecules are oxidized to release an $\mathrm{O}_{2}$ molecule.

As inspired by nature, water splitting is promoted in artificial energy conversion schemes. Owing to its ability to generate $\mathrm{O}_{2}$ and $\mathrm{H}_{2}$ via photocatalytic, electrocatalytic, or photoelectrocatalytic processes, water splitting could convert both light and electrical energy to chemical energy. Considering that electrical energy can be generated from renewable but intermittent energy sources, such as solar, wind, and hydropower, the $\mathrm{H}_{2}$ generated using these processes is, therefore, considered a renewable and clean energy resource. As one of the half reactions of water splitting, water oxidation is a thermodynamically uphill reaction and kinetically sluggish reaction because it requires the combination of the transfer of four electrons, breaking four $\mathrm{O}-\mathrm{H}$ bonds, and formation of $\mathrm{O}-\mathrm{O}$ bonds in a concerted manner [8-11]. Therefore, water oxidation is the bottleneck for performing large-scale water splitting. Extensive efforts have been made in the past decades to develop highly efficient water oxidation catalysts (WOCs), and a variety of molecular transition metal complexes have been identified as active WOCs [8,12-20]. However, the water oxidation reaction mechanism, particularly the key $0-0$ bond formation step, has not been fully elucidated. Therefore, it is essential to elucidate the reaction mechanisms and fundamental steps, particularly the $0-0$ bond formation process of the water oxidation reaction, for the rational design of efficient catalysts.

Five main types of $\mathrm{O}-\mathrm{O}$ bond formation mechanisms have been proposed in the literature (Scheme 1), viz. (1) the water nucleophilic attack (WNA) to a terminal metal oxo/oxyl unit (also known as the acid-base mechanism), (2) coupling between two metal oxo/oxyl units, typically known as the I2M pathway, (3) coupling between two hydroxyl units either on different metal ions (bimolecular hydroxyl coupling; BHC) or the same metal ion (intramolecular hydroxyl coupling IHC), (4) (a)

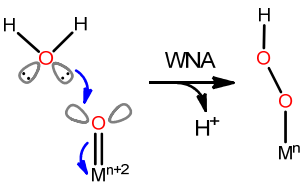

(c)



(e)

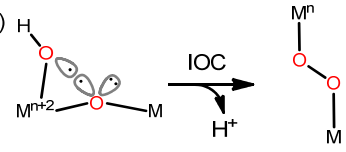

(d)

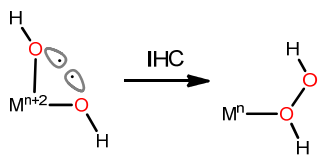

(f)





Scheme 1. Schematic diagrams of proposed $0-0$ bond formation mechanisms: (a) water nucleophilic attack (WNA), (b) coupling between two metal oxo/oxyl units (I2M), (c) bimolecular hydroxyl coupling (BHC), (d) intramolecular hydroxyl coupling (IHC), (e) intramolecular coupling between hydroxyl and bridging oxo (intermolecular oxo/oxyl coupling; IOC), and (f) coupling between two bridging oxo units (redox isomerization; RI). intramolecular oxo/oxyl coupling (IOC), and (5) redox isomerization (RI). In the following sections, we will discuss the aforementioned mechanisms and summarize the recent experimental and theoretical results that support these mechanisms. This review provides a mechanistic understanding of various metal centers and ligand structures, and sheds light on the rational design of more efficient WOCs.

\section{WNA mechanism}

When $\mathrm{O}-\mathrm{O}$ bonds form via the WNA mechanism, a nucleophilic dissociative $\mathrm{H}_{2} \mathrm{O}$ molecule attacks a metal-bound electrophilic oxo group; that leads to the formation of an $0-0 \sigma$ bond, breaking of one of the $\mathrm{M}-0 \pi$ bonds, and typical $2 \mathrm{e}^{-}$reduction of the metal center. The metal center should be electrophilic to accept the $\mathrm{p}$ electrons from the oxo ligand during the WNA-type 0-O bond formation reaction, which indicates that the WNA mechanism would be unfavorable when mediated by later transition metals with numerous d-orbital electrons. The WNA 0-O bond formation generates metal-hydroperoxide (M-OOH) species, which undergo further oxidation to release $\mathrm{O}_{2}$. Anions in alkaline solutions, such as the hydroxide, acetate, and nitrate anions, could be potential nucleophiles in this process.

\subsection{Traditional WNA mechanism}

The WNA mechanism has been extensively studied using Ru-based WOCs. Ru centers are redox-active and the presence of two Ru centers in close proximity was determined to be essential for active WOCs. In their pioneering study, Meyer et al. [21] demonstrated the possibility of the multielectron oxidation of $\mathrm{H}_{2} \mathrm{O}$ to $\mathrm{O}_{2}$, and reported that an oxo-bridged binuclear $\mathrm{Ru}$ complex, viz. cis,cis-[(bpy) $\left.{ }_{2}\left(\mathrm{H}_{2} \mathrm{O}\right) \mathrm{Ru}(\mu-\mathrm{O}) \mathrm{Ru}\left(\mathrm{H}_{2} \mathrm{O}\right)(\mathrm{bpy})_{2}\right]^{4+}$ (1), where bpy denotes bipyridine, known as the "blue dimer" owing to its characteristic blue color, which contained bipyridyl ligands, could mediate the $4 \mathrm{e}^{-}-4 \mathrm{H}^{+}$oxidation of $\mathrm{H}_{2} \mathrm{O}$ molecules. It was hypothesized that the $\mathrm{Ru}_{2}{ }^{\mathrm{IIIIII}}$ complex was first oxidized to a high-valent $\mathrm{Ru}_{2} \mathrm{~V}, \mathrm{~V}$ intermediate (two $\mathrm{Ru}^{\mathrm{V}}=\mathrm{O}$ entities) by the added $\mathrm{Ce}^{\mathrm{IV}}$ oxidants; subsequently, the electron-deficient $\mathrm{Ru}^{\mathrm{V}}=\mathrm{O}$ moiety was nucleophilically attacked by an external $\mathrm{H}_{2} \mathrm{O}$ molecule, which resulted in the formation of hydroperoxido species (Scheme 2). The hydroperoxido species would undergo further oxidation to release $\mathrm{O}_{2}$. The oxo-bridge was estimated to play a crucial role in electronic delocalization, which would allow a fleet valence equilibrium between the bimetallic centers. This mechanistic scenario was confirmed using isotope-labelling experiments, and ab initio calculations, as reported by Meyer et al. [21] and Baik et al. [22], respectively. The ab initio calculations revealed that a typical intramolecular ligand-to-metal charge transfer process occurred in the high-valent $\mathrm{Ru}_{2} \mathrm{~V}, \mathrm{~V}$ intermediate when it reacted with $\mathrm{H}_{2} \mathrm{O}$ to generate the $\mathrm{Ru}^{\mathrm{IV}}-\mathrm{O}$ radicaloid. The $\mathrm{Ru}^{\mathrm{IV}}-\mathrm{O} \cdot$ species acted as strong oxidants that attacked $\mathrm{H}_{2} \mathrm{O}$ molecules and homolitically cleaved the $\mathrm{O}-\mathrm{H}$ bonds. However, the calculations performed by Baik et al. could not explain the generation of the experimentally observed solvent-derived dioxygen species. Conversely, Hurst et al. [23] 




Scheme 2. Molecular structure of $\mathbf{1}$ blue dimer, where bpy denotes bipyridine, and proposed oxo-bridged binuclear $\mathrm{Ru}$ complex-mediated water nucleophilic attack $\mathrm{O}-\mathrm{O}$ bond formation mechanism.

proposed that a $\mathrm{H}_{2} \mathrm{O}$ molecule would nucleophilically attack the pyridine ring instead of the $\mathrm{Ru}^{\mathrm{V}}=\mathrm{O}$ moiety (Scheme 2). Subsequently, the generated $\mathrm{Ru}_{2} \mathrm{~V}, \mathrm{IV}-$ pyridine- $\mathrm{OH} \cdot$ radicals would be quenched by the attack of a second $\mathrm{H}_{2} \mathrm{O}$ molecule, and would further couple to release $\mathrm{O}_{2}$. The $\mathrm{Ru}^{\mathrm{V}}=\mathrm{O} / \mathrm{Ru}^{\mathrm{IV}}=\mathrm{OH}$ moieties in the proposed mechanism acted as Lewis bases to facilitate the $\mathrm{O}-\mathrm{H}$ bonding of the solvent $\mathrm{H}_{2} \mathrm{O}$ molecules. Moreover, Mayer et al. [24] reported a tripyridyl-containing oxo-bridged binuclear $\mathrm{Ru}$ complex, which presented a stable $\mathrm{Ru}_{2} \mathrm{~V}, \mathrm{~V}$ intermediate and excellent water oxidation capability.

A variety of mononuclear complexes were reported to mediate the $4 \mathrm{e}^{-}$oxidation of $\mathrm{H}_{2} \mathrm{O}$. Thummel et al. [25-27] reported a series of mononuclear $\mathrm{Ru}$ complexes, which were demonstrated to promote water oxidation. The WNA pathway was proposed as the $\mathrm{O}-\mathrm{O}$ bond formation mechanisms of the reported mononuclear Ru complexes. Meyer et al. [28] performed a detailed mechanistic investigation of the water oxidation promotion using a typical mononuclear Ru aqua complex, viz. $\left[\mathrm{Ru}(\mathrm{tpy})(\mathrm{bpm})\left(\mathrm{OH}_{2}\right)\right]^{2+}(2)$, where tpy and bpm denote tripyridine and 2,2'-bipyrimidine, respectively. Two sequential proton-coupled electron transfer (PCET) processes were estimated to occur during the oxidation of $\mathrm{Ru}^{\mathrm{II}}-\mathrm{H}_{2} \mathrm{O}$ to $\mathrm{Ru}^{\mathrm{IV}}=\mathrm{O}$ species. Furthermore, the $1 \mathrm{e}^{-}$oxidation of $\mathrm{Ru}^{\mathrm{IV}}=\mathrm{O}$ to $\mathrm{Ru}^{\mathrm{V}}=\mathrm{O}$ triggered the water oxidation reaction via the WNA mechanism. The formed peroxidic $\mathrm{Ru}^{\mathrm{III}}-\mathrm{OOH}$ complex further underwent $1 \mathrm{e}^{-}$ oxidation to generate the key intermediate $\mathrm{Ru}^{\mathrm{IV}}-\mathrm{OO}$. The $\mathrm{Ru}^{\mathrm{IV}-\mathrm{OOO}}$ intermediate consisted of a seven-coordinated Ru(IV) center and side-on bidentate peroxide $\left(\eta^{2}\right)$. Calculations indicated that the six-coordinated isomer with a terminal peroxide ligand was less stable. The proposed water oxidation cycle is presented in Scheme 3. The facile coordination of the $\mathrm{H}_{2} \mathrm{O}$ molecules at the metal center to a vacant site was important for generating the active catalyst forms of the aqua species. Sakai et al. confirmed that the aqua species were the active intermediates and the chloride effect, which facilitated the access to

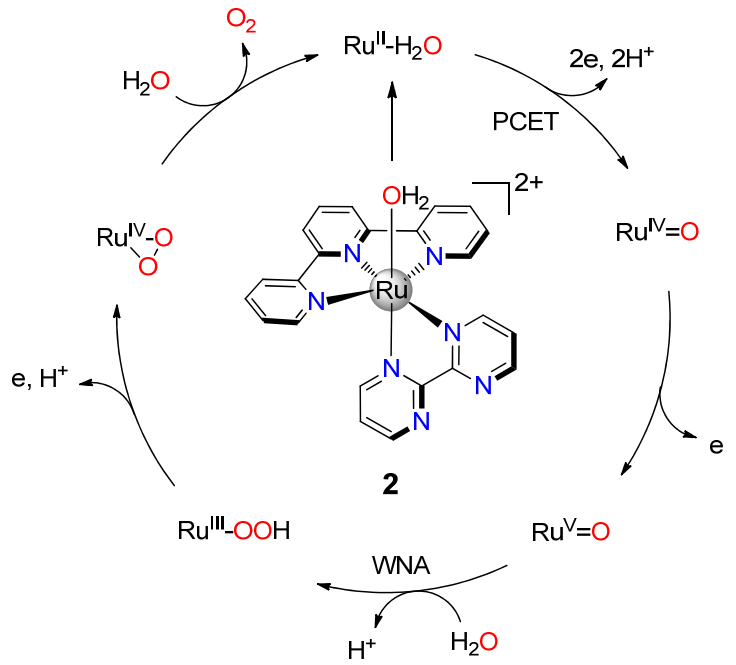

Scheme 3. Molecular structure of $\mathbf{2}$ and proposed water oxidation catalytic cycle

vacant coordination sites for $\mathrm{H}_{2} \mathrm{O}$ molecules at the metal center, was important [29]. Furthermore, it was demonstrated that the electron-withdrawing groups slowed down the chloride-aqua ligand exchange reaction [29,30]. Berlinguette et al. conducted detailed mechanistic studies on $\left[\mathrm{Ru}(\mathrm{tpy})(\mathrm{bpy})\left(\mathrm{OH}_{2}\right)\right]^{2+}$-type complexes and the bpy ligand located trans to the Ru-aqua moiety, which affected the catalytic behavior and reaction pathways of mononuclear Ru complexes [30,31]. Meyer et al. [32] reported a variety of mononuclear Ru-aqua analogues and proposed that the $\mathrm{O}-\mathrm{O}$ bond formation mechanism was WNA.

A cis bipyridyl-based mononuclear Ru photosensitizer complex 3 was analyzed by Llobet et al. [33] who determined that the typical photosensitizer $\mathbf{3}$ was capable of water oxidation (Scheme 4). The $\mathrm{Ru}^{\mathrm{IV}}=0$ intermediate was estimated to be generated after 3 lost $4 \mathrm{e}^{-}$and $4 \mathrm{H}^{+}$. The calculated free energy barrier of the WNA-type $0-0$ bond formation step was 24.5 $\mathrm{kcal} / \mathrm{mol}$, which was $33.0 \mathrm{kcal} / \mathrm{mol}$ lower than the energy barrier of the IOC 0-O bond formation reaction. Llobet et al. [33] revealed that unpaired spin densities were found on both the $\mathrm{Ru}$ and $\mathrm{O}$ atoms in the complex formed via the removal of $4 \mathrm{e}^{-}$ and $4 \mathrm{H}^{+}$from 3 , which indicated that the $\mathrm{Ru}$ oxidation state was lower than the typical value of VI and the metal-oxo species presented radicaloid nature. Furthermore, the distinctly high energy barrier of the IOC $\mathrm{O}-\mathrm{O}$ bond formation pathway confirmed the difficulty of the IOC process at the stable six-coordinated metal center.

A WOC with a strong $\sigma$-donating but weak $\pi$-accepting ligand would decrease the oxidation potential of the water split-

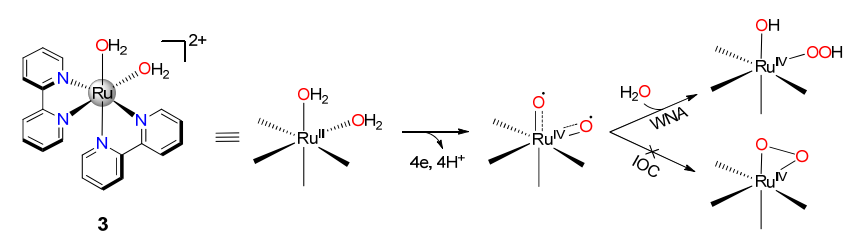

Scheme 4. Molecular structure of 3 , and water nucleophilic attack (WNA) and intramolecular oxo/oxyl coupling (IOC) $\mathrm{O}-\mathrm{O}$ bond formation pathways. 
ting reaction. Sakai et al. [34] reported a mononuclear Ru complex with a $\sigma$-donating triazamacrocyclic ligand, which presented lower oxidation potentials for the $\mathrm{Ru}^{\mathrm{III}} / \mathrm{Ru}^{\mathrm{II}}$ and $\mathrm{Ru}^{\mathrm{IV}} / \mathrm{Ru}^{\mathrm{III}}$ couples than the polypyridyl analogues. Zhao et al. [35] reported a series of mononuclear Ru complexes containing tris(2-pyridylmethyl)amine-related ligands, which were demonstrated to be able to mediate the water oxidation reaction via the WNA pathway. Moreover, Llobet et al. [36] reported the remarkable water oxidation activity of a series of mononuclear $\mathrm{Ru}$ complexes comprising pyridine-functionalized abnormal triazolylidene carbene ligands, and their catalytic behavior was ascribed to the strong $\sigma$-donating properties of the abnormal carbene ligands.

Kärkäs et al. [37] reported that two mononuclear Ru complexes containing benzo[d]imidazole ligands and anionic carboxylate terminal groups, viz. [(Hhpbc) Ru(pic) $\left.]_{3}\right]^{+}(4)$ and $\left[(\mathrm{Hhpb}) \mathrm{Ru}(\mathrm{pic})_{3}\right]^{+}(\mathbf{5})$, where $\mathrm{H}_{3} \mathrm{hpbc}, \mathrm{H}_{3} \mathrm{hpb}$, and pic denote 2-(2-hydroxyphenyl)-1H-benzo[d]imidazole-7-carboxylic acid 2-(2-hydroxyphenyl)-1H-benzo[d]imidazol-7-ol, and 4-methylpyridine, respectively, facilitated the WNA-type water oxidation reaction. The excellent catalytic performance of $\mathbf{4}$ and $\mathbf{5}$ was attributed to the incorporation of the benzo[d]imidazole moiety in their structures, which enabled the facile protonation or deprotonation and subsequent plausible PCET [38]. Charge accumulation and the formation of damaging high-energy intermediates would be avoided during the PCET processes, which were estimated to facilitate the oxidation of $\mathrm{H}_{2} \mathrm{O}$ molecules especially under large overpotentials. Åkermark and Liao [37] proposed that the reaction catalyzed by $\mathbf{4}$ involved the nucleophilic attack of $\mathrm{H}_{2} \mathrm{O}$ on a $\mathrm{Ru}^{\mathrm{VI}}=\mathrm{O}$ species to generate a $\mathrm{Ru}^{\mathrm{IV}}$-hydroperoxo intermediate. However, typical $\mathrm{Ru}^{\mathrm{VII}}=\mathrm{O}$ species were formed during the WNA-type $0-0$ bond formation reaction over the phenolate-containing $\mathbf{5}$, and $\mathbf{5}$ would be better described as presenting a $\mathrm{Ru}^{\mathrm{V}}$ center and $2 \mathrm{e}^{-}$-oxidized ligand backbone (Scheme 5). The uncommon formation of such high-valent species was ascribed to the redox-active phenolate terminal groups of the ligand. The combination of benzo[d]imidazole and redox-active ligand contained a high-valent Ru-oxo species, which triggered the subsequent WNA-type 0-O bond formation. In addition, Åkermark et al. reported a single-site $\mathrm{Ru}$ complex, $\left[\mathrm{Ru}(\mathrm{bpb})(\mathrm{pic})_{2}\right]^{+}$, where $\mathrm{H}_{2} \mathrm{bpb}$ denotes $N, N^{\prime}$-(1,2-phenylene)-bis(2-pyridine-carboxamide), which contained a tetra-coordinated $\mathrm{N}$-amidato ligand. The addition of $\mathrm{CO}$ to this complex would result in the deactivation of the complex of interest. The $\mathrm{N}$-amidato ligand featured strong $\sigma$-donating ability, and thus, it could better stabilize the high-valent metal-oxo species. Therefore, a high-valent $\mathrm{Ru}^{\mathrm{VI}}=0$

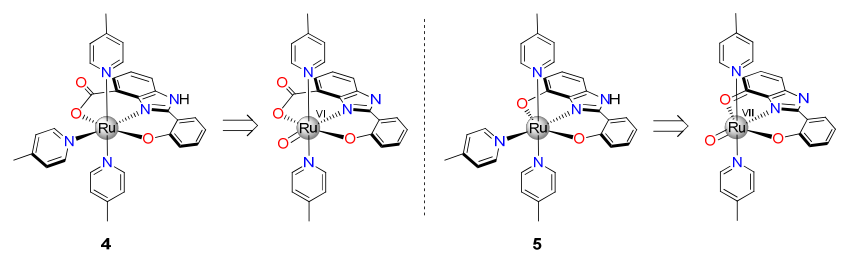

Scheme 5. Molecular structures of $\mathbf{4}$ and 5, and their respective key intermediates that are nucleophilically attacked by solvent $\mathrm{H}_{2} \mathrm{O}$ molecules. intermediate rather than the typical $\mathrm{Ru}=\mathrm{V}=0$ species was formed, which triggered water oxidation. However, the lack of catalytic properties of the CO-containing complexes for the water oxidation reaction has not been properly elucidated yet [39].

Combined experimental and theoretical investigations were conducted by Llobet et al. [40], who reported that the mononuclear $\mathrm{Ru}$ complex bearing dangling carboxylate $\left(\mathrm{Ru}(\mathrm{tda})(\mathrm{py})_{2}\right.$ complex (6), where $\mathrm{H}_{2} \mathrm{tda}$ and py denote $\left[2,2^{\prime} ; 6^{\prime}, 2^{\prime \prime}\right]$-terpyridine-6,6"-dicarboxylic acid and pyridine, respectively, could significantly boost water oxidation owing to its ability to decrease the energy barrier of the $\mathrm{O}-\mathrm{O}$ bond formation reaction. Two sequential PCET processes occurred to generate a seven-coordinated $\mathrm{Ru}^{\mathrm{IV}}=\mathrm{O}$ intermediate. The further oxidation of $\mathrm{Ru}^{\mathrm{IV}}=\mathrm{O}$ to high-valent $\mathrm{Ru}^{\mathrm{V}}=\mathrm{O}$ required the potential of $1.32 \mathrm{~V}$. Then, $\mathrm{Ru}=0$ would be nucleophilically attacked by a $\mathrm{H}_{2} \mathrm{O}$ molecule with the activation free-energy barrier of 19.5 $\mathrm{kcal} / \mathrm{mol}$. The decrease in the energy barrier of the $\mathrm{O}-\mathrm{O}$ bond formation reaction was ascribed to the significant intramolecular proton transfer to the dangling carboxylate during the formation of 0-0 bonds. Tessier et al. [41] revisited the role of the seven-coordination during Ru-catalyzed water oxidation reaction. A series of Ru complexes that contained penta-dentate ligands and pyridine were prepared and characterized; moreover the interplay between the six- and seven-coordination at different oxidation states and the important role of the terminal dangling carboxylate located in close proximity to the $\mathrm{Ru}^{\mathrm{V}}=\mathrm{O}$ moiety, which acted both as H-bonding site and internal base to accept proton from the nucleophile $\mathrm{H}_{2} \mathrm{O}$ molecule (Scheme 6), was highlighted. The combined experimental data and theoretical results indicated that anionic ligands reduced the redox potential of the $\mathrm{Ru}^{\mathrm{V}}=\mathrm{O} / \mathrm{Ru}^{\mathrm{IV}}-\mathrm{OH}$ couple, and seven-coordination was not necessary particularly for the WNA-type 0-O bond formation.

Meyer et al. [42] investigated the electron transfer mediator effects during the water oxidation reaction using $\mathrm{Ru}(\mathrm{bda})(\mathrm{L})_{2}$ catalysts, where $\mathrm{H}_{2}$ bda and $\mathrm{L}$ denote 2,2'-bipyridine$6,6^{\prime}$-dicarboxylic acid and the ligand, respectively, and redox mediators, and revealed the dependence on the redox potential of the mediator. In addition, the experimental results demonstrated the important role of the atom-proton transfer (APT) process and $\mathrm{O}$-atom transfer to the $\mathrm{O}$ atom of a $\mathrm{H}_{2} \mathrm{O}$ molecule combined with the proton transfer to the added $\mathrm{HPO}_{4}{ }^{2-}$ buffer base during water oxidation over $\left[\mathrm{Ru}^{\mathrm{V}}(0)\right]^{+}$.

$\mathrm{Ru}^{\mathrm{V}}(\mathrm{O})^{+}+\mathrm{H}-\mathrm{O}-\mathrm{H}---$ Base $\stackrel{\text { WNA }}{\longrightarrow}\left[\mathrm{Ru}^{\mathrm{III}}(\mathrm{OOH})\right]+$ Hbase $^{+}$Eq. (1)

The water oxidation mechanism over mononuclear Ru-based catalysts was further investigated by Meyer [28,43-45], Berlinguette [31], Fujita [46], Voorhis [47], Llobet



Scheme 6. Molecular structure of $\mathbf{6}$ and water nucleophilic attack of the $\mathrm{Ru}^{\mathrm{V}}=\mathrm{O}$ moiety. 
[48], Sun [49-52], Sakai [53], Fukuzumi [54], Buda [55], Yang [56], and Chen [57]. The typical water oxidation catalytic cycle mediated by mononuclear Ru complexes, where the $0-0$ bond formation follows the WNA pathway, is summarized in Scheme 7. Two consecutive PCET processes from the Ru-aqua complex, $\mathrm{Ru}^{\mathrm{II}}-\mathrm{OH}_{2}$, to high-valent $\mathrm{Ru}^{\mathrm{IV}}=\mathrm{O}$ species are followed by the $1 \mathrm{e}^{-}$-oxidation of $\mathrm{Ru}^{\mathrm{IV}}=0$ to $\mathrm{Ru}^{\mathrm{V}}=0$. The $\mathrm{Ru}^{\mathrm{V}}=0$ species are the key intermediates that are nucleophilically attacked by solvent $\mathrm{H}_{2} \mathrm{O}$ molecules to trigger the formation of $\mathrm{O}-\mathrm{O}$ bonds. The metal-hydroperoxo intermediate, $\mathrm{Ru}^{\mathrm{III}}-\mathrm{OOH}$, is subsequently formed, and further undergoes PCET to be oxidized to the peroxo complex, $\mathrm{Ru}^{\mathrm{IV}}-\mathrm{OO}$. Lastly, $\mathrm{O}_{2}$ is liberated via substitution with a $\mathrm{H}_{2} \mathrm{O}$ molecule, and the $\mathrm{Ru}^{\mathrm{II}}$-aqua complex is regenerated. In addition, the $\mathrm{Ru}^{\mathrm{IV}}=\mathrm{O}$ species are responsible for WNA-type $\mathrm{O}-\mathrm{O}$ bond formation. Alternatively, the peroxo complex, $\mathrm{Ru}^{\mathrm{IV}}-\mathrm{OO}$, is further oxidized to generate the high-valent $\mathrm{Ru}^{\mathrm{V}}-\mathrm{OO}$ intermediate, and the latter complex undergoes rapid $\mathrm{O}_{2}$ release and deprotonation of the metal-bound $\mathrm{H}_{2} \mathrm{O}$ to generate RuIII-OH species.

Similar to $\mathrm{Ru}$ centers, Ir centers are redox active and have been widely used as WOCs. Bernhard et al. reported a mononuclear cyclometalated Ir complex $\left[\operatorname{Ir}(\mathrm{ppy})_{2}\left(\mathrm{H}_{2} \mathrm{O}\right)_{2}\right]^{+}$(7), where ppy is cyclometalated phenylpyridine, which presented water oxidation properties in the presence of $\mathrm{C} \mathrm{Ce}^{\mathrm{V}}$ sacrificial oxidant. It was demonstrated that the preliminary ligand exchange process on the six-coordinated Ir center was necessary for the WNA-type $0-0$ bond formation [58]. The $\mathrm{Ir}^{\mathrm{V}}=\mathrm{O}$ species was hypothesized to be the active catalytic species as $\left[\operatorname{Ir}(\mathrm{O})(\mathrm{X})(\mathrm{ppy})_{2}\right]$, where $\mathrm{X}$ could be $\mathrm{OH}_{2}, \mathrm{OH}$, or $\mathrm{O}^{2-}$ depending on the pH. Lledós et al. [59] indicated that the $\mathrm{X}$ moiety would act as internal base to promote the WNA-type 0-0 bond formation (Scheme 8), and reported that the $\left[\operatorname{Ir}(0)_{2}(\mathrm{ppy})_{2}\right]^{-}$species with the most basic internal base presented the lowest energy barrier for $\mathrm{O}-\mathrm{O}$ bond formation.

Author et al. [60] reported a mononuclear Ir complex 8 bearing the cyclopentadiene $\left(\mathrm{Cp}^{*}\right)$ ligand, which was introduced to increase the electron density and increase the number

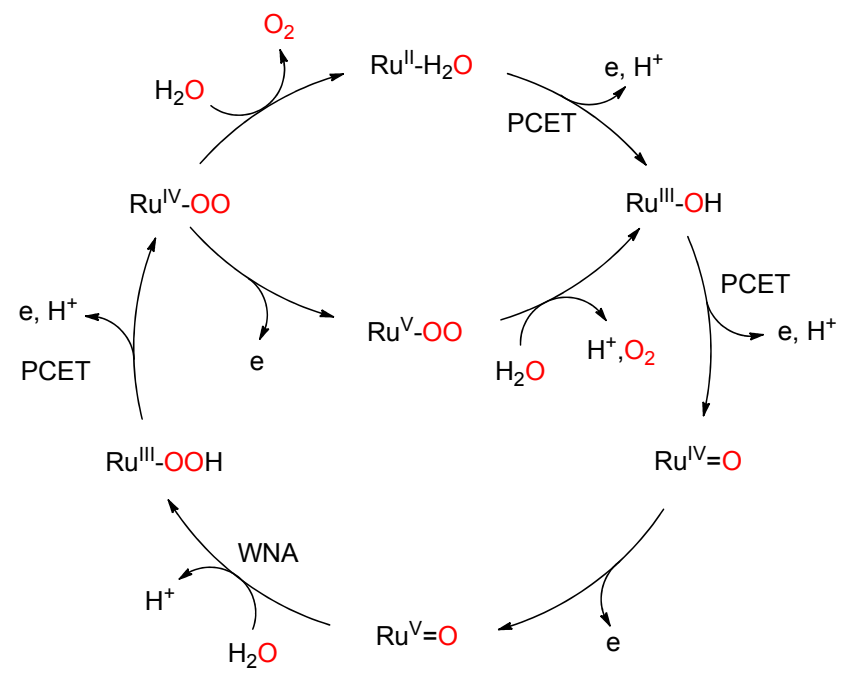

Scheme 7. Proposed catalytic cycle of mononuclear Ru-mediated water oxidation; the $\mathrm{O}-\mathrm{O}$ bond formation mechanism follows the water nucleophilic attack (WNA) pathway.


7
Scheme 8. Molecular structure of 7 and schematic of base-assisted solvent $\mathrm{H}_{2} \mathrm{O}$ nucleophilic attack of the $\mathrm{Ir}^{\mathrm{V}}=\mathrm{O}$ moiety.

of available coordination sites of the Ir center. The water oxidation capability of the $\mathrm{Cp}^{*}$-containing mononuclear Ir complex was higher than that of the mononuclear Ru counterpart. Subsequently, Author et al. substituted the cyclometalated ligand with bipyridine or its analogue to obtain the piano stool-like mononuclear Ir complex 9 [60]. The $\operatorname{Ir}^{\mathrm{V}}=0$ species was demonstrated to be the key intermediate to trigger the subsequent WNA-type 0-O bond formation. Furthermore, it was reported that the nature of the proton acceptor significantly affected the energy barrier of the key 0-0 bond formation step, and the participation of an outer-sphere $\mathrm{H}_{2} \mathrm{O}$ molecule would substantially decrease the energy barrier (Scheme 9). An Ir hydroperoxide species was generated afterward, and that would further undergo oxidation to release $\mathrm{O}_{2}$ [61]. In addition, Macchioni et al. [62] proposed an alternative reaction pathway for the Ir-catalyzed water oxidation reaction, in which the sacrificial oxidant, cerium ammonium nitrate (CAN), presented an important role during the $\mathrm{O}-\mathrm{O}$ bond formation step (Scheme 9). A significant WNA-type 0-O bond formation transition state was identified, in which the $\left[\mathrm{Ce}^{\mathrm{IV}}\left(\mathrm{NO}_{3}\right)_{3}(\mathrm{OH})\right]$ complex directly interacted with the IrIV-O $^{\mathrm{IV}}$ species and a nucleophile $\mathrm{H}_{2} \mathrm{O}$ molecule. The energy barrier of the CAN-driven $\mathrm{O}-\mathrm{O}$ bond formation reaction was calculated to be significantly lower than those of the I2M and conventional WNA pathways.

Siegbahn et al. [63] theoretically analyzed the oxidation states of Ir that led to $\mathrm{O}-\mathrm{O}$ bond formation during the
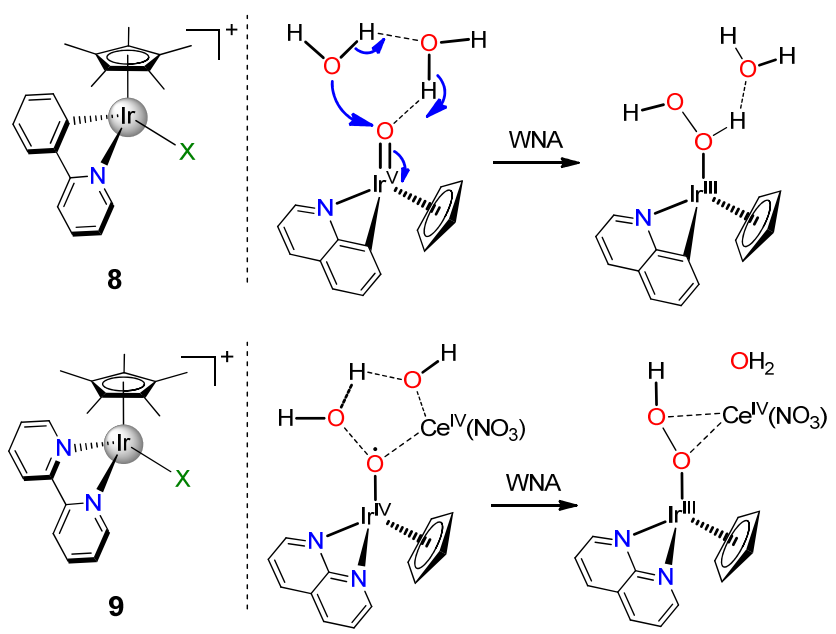

Scheme 9. Molecular structures of $\mathbf{8}$ and 9. Proposed water nucleophilic attack (WNA) pathway of $\mathrm{O}-\mathrm{O}$ bond formation, which involved the participation of an outer-sphere $\mathrm{H}_{2} \mathrm{O}$ molecule or the $\left[\mathrm{Ce}{ }^{\mathrm{IV}}\left(\mathrm{NO}_{3}\right)_{3}(\mathrm{OH})\right]$ complex. 
Cp*Ir(bpy)Cl-catalyzed water oxidation reaction. The [(bpy) $\left.\operatorname{Ir}\left(\mathrm{H}_{2} \mathrm{O}\right)_{2}\left(\mathrm{CH}_{3} \mathrm{COO}\right) \mathrm{Cl}\right]^{+}$species was considered to be the active catalyst at the higher oxidation state. Furthermore, the authors calculated that the $\mathrm{O}-\mathrm{O}$ bond formation occurred at the high typical oxidation states of IrVI and IrVI, rather than IrV. A WNA-type $\mathrm{O}-\mathrm{O}$ bond formation reaction occurred, and was facilitated by the acetate ligand, which acted as internal base during the nucleophilic attack and abstracted a proton.

In addition to the extensive studies on the water oxidation reaction mediated by noble metals, increasing efforts have been made toward the mechanistic elucidation of the $\mathrm{O}-\mathrm{O}$ bond formation pathways over earth-abundant metal-based WOCs [64-66]. Typically, more experimental details could be found on noble-metal catalyzed reactions than on first-row transition-metal catalyzed reactions owing to the relatively high stability of noble metal-oxygen species. In addition, more mechanistic uncertainties exist for the first-row transition-metal-based reactions owing to the scarce experimental details, complex theoretical approaches, and also the various oxidation states and fluctuating electronic spin populations of these metals. In addition, because first-row transition metal-oxygen species are less stable than their noble metal counterparts, direct coupling of two metal-oxygen radicals to generate $0-0$ bonds scenarios have been rarely reported.

Mn-based WOCs were selected for PSII, and many synthetic Mn-containing complexes were reported as WOCs. In 2007, Sun et al. [67] reported the first well-investigated mononuclear site hangman Mn complex 10. The detailed theoretical analysis of $\mathrm{Mn}$-corrole related complexes revealed that the typical $\mathrm{MnV}=0$ species were responsible for the formation of the 0-0 bonds, and the nucleophilic attack of the hydroxide anions on the $\mathrm{Mn}=0$ species was proposed $[68,69]$. Borovik et al. [70] calculated that the $\mathrm{MnV}=0$ complex rather than the $\mathrm{Mn}^{\mathrm{IV}}-\mathrm{O} \cdot$ radical was the most oxidized species. In addition, Liao et al. [71,72] proposed a PSII-like water oxidation mechanism using a bioinspired tetranuclear Mn complex, in which the crucial $0-0$ bond formation reaction proceeded via the direct coupling of a $\mathrm{Mn}^{\mathrm{IV}}$-oxyl radical and di-Mn bridging oxo group.

Ellis et al. [73] reported that the Fe(III)-tetraamido macrocyclic ligand, Fe ${ }^{\text {III-TAML }}$ (11), catalyst could be an efficient WOC. Fillol et al. [74] determined that Fe complexes of tetradentate neutral ligands acted as WOCs at low $\mathrm{pH}$ with substantial TON (the representative cis-vacant Fe complex $\mathbf{1 2}$ is illustrated in Scheme 10). The spectra and kinetic analysis results of these Fe complexes demonstrated that high-valent Fe-oxo species were responsible for the $0-0$ formation reaction. The WNA-type $0-0$ bond formation mechanism was postulated based on the results of the kinetic studies, which indicated that the reaction rate followed first order kinetics in respect to the concentration of the observed $\mathrm{Fe}^{\mathrm{IV}}=\mathrm{O}$ species. $\mathrm{O}=\mathrm{Fe}^{\mathrm{IV}}-(\mathrm{OH})-\mathrm{Ce}^{\mathrm{IV}}$, which contained a bridging hydroxyl group, was suggested to be the reaction intermediate. The subsequent oxidation of $\mathrm{O}=\mathrm{Fe}^{\mathrm{IV}}-(\mathrm{OH})-\mathrm{Ce}^{\mathrm{IV}}$ led to the formation of $\mathrm{O}=\mathrm{Fe}^{\mathrm{V}}-(\mathrm{OH})-\mathrm{Ce}^{\mathrm{IV}}$, which was nucleophilically attacked by a $\mathrm{H}_{2} \mathrm{O}$ molecule, afterward [75]. A series of analogues of $\mathbf{1 2}$ with cis-vacant coordination sites were also reported [76-79]. Meyer et al. [80] proposed the existence of the key $\mathrm{Fe}^{\mathrm{V}}=\mathrm{O}$ intermediate, which trig-

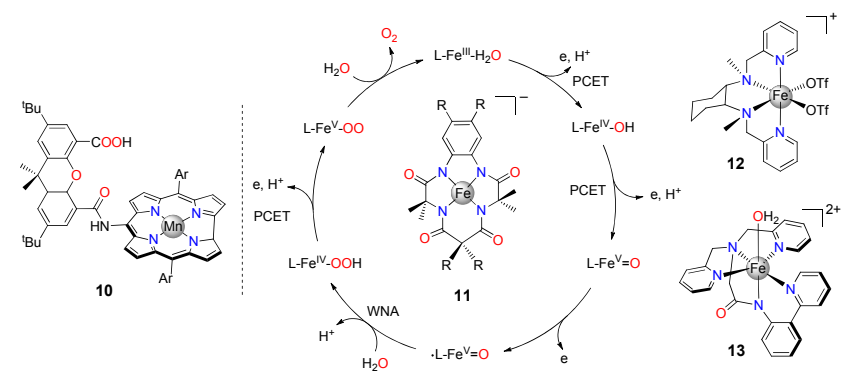

Scheme 10. Molecular structures of 10, 11, 12 and 13, and proposed 11-mediated water nucleophilic attack (WNA)-type water oxidation catalytic cycle.

gered the subsequent WNA-type $0-0$ bond formation. In addition, Panda et al. [81] confirmed the existence of $\mathrm{Fe}^{\mathrm{V}}=\mathrm{O}$ species in the reaction mixture. Cramer et al. [82] and Liao et al. [83] calculated that the oxidation of the initial TAML-Fe ${ }^{\text {III- }}-\mathrm{OH}_{2}$ complex led to the formation of TAML $\cdot-\mathrm{Fe}^{\mathrm{V}}=\mathrm{O}$ species, which subsequently underwent nucleophilic attack by a $\mathrm{H}_{2} \mathrm{O}$ molecule, and the TAML of the $\mathrm{Fe}^{\mathrm{V}}=0$ species underwent $1 \mathrm{e}^{-}$oxidation. The Fe-TAML-catalyzed water oxidation reaction is schematically presented in Scheme 10. The Fe-oxo species responsible for the $\mathrm{O}-\mathrm{O}$ bond formation process was found to differ with different added sacrificial oxidants. Che et al. [84] determined that the key intermediates that triggered the $0-0$ bond formation process were the $\mathrm{Fe}^{\mathrm{IV}}=\mathrm{O}$ or $\mathrm{Fe}^{\mathrm{V}}=\mathrm{O}$ species when the oxidant regents were $\mathrm{CAN}$ or $\mathrm{NaIO}_{4}$ (or oxone), respectively.

A WNA-like $\mathrm{O}-\mathrm{O}$ bond formation mechanism was reported by Liao et al. [85]. Water oxidation mediated by a mononuclear Fe complex with a square polypyridine ligand was theoretically investigated, and the typical $\mathrm{Fe}^{\mathrm{V}}=\mathrm{O}$ intermediate was determined to be directly responsible for $\mathrm{O}-\mathrm{O}$ bond formation. The energy barrier of the $\mathrm{O}-\mathrm{O}$ bond formation reaction that occurred via the conventional WNA mechanism using a $\mathrm{H}_{2} \mathrm{O}$ nucleophile was calculated to be higher than that of the corresponding reaction in which the nitrate anion was used as the nucleophile.

Nocera et al. [86] studied the electrocatalytic water oxidation over $\mathrm{Co}^{\mathrm{III}}$ hangman corrole complexes 14 bearing $\beta$-octafluoro and meso-pentafluorophenyl substituents and reported that the catalytic performance of these complexes was excellent. $\mathrm{A} \mathrm{Co}^{\mathrm{IV}}$-corrole ${ }^{\bullet+}$ moiety was proposed to be the catalytically active species. Cramer et al. [87] and Lai et al. [88] further investigated the water oxidation reaction mechanisms. The typical $\mathrm{Co}^{\mathrm{V}}$ species (better described as $\mathrm{Co}^{\mathrm{IV}}$-corrole ${ }^{\bullet+}$ with cation radical character in the corrole ring) was reconfirmed as the key intermediate to trigger the WNA-type 0-O bond formation reaction, rather than Co(IV). In addition, the pendant hangman carboxyl moiety of the complex was determined to act as intramolecular base to facilitate the APT process during the WNA-type 0-O bond formation reaction (Scheme 11) [89].

Lei et al. [90] systematically investigated the Co-corrole complex-mediated water oxidation reactions. $\mathrm{H}_{2} \mathrm{O}-\mathrm{Co}^{\mathrm{III}}$-corrole underwent two sequential $1 \mathrm{H}^{+} / 1 \mathrm{e}^{-}$oxidation steps to form $\mathrm{HO}^{--}-\mathrm{Co}^{\mathrm{III}}$-corrole ${ }^{\bullet}$, which further underwent WNA to generate HOO-CoIII-corrole. The calculated energy barrier of the $\mathrm{O}-\mathrm{O}$ bond formation reaction using an acetate anion as the external 


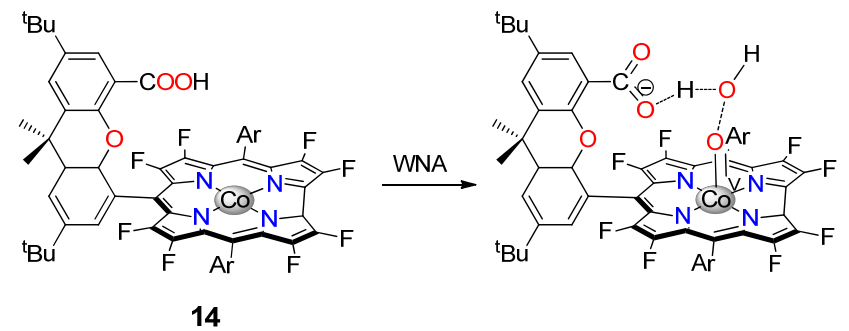

Scheme 11. Molecular structure of 14, and proposed hangman-assisted water nucleophilic attack (WNA)-type 0-0 bond formation mechanism.

proton-acceptor base was $11.8 \mathrm{kcal} / \mathrm{mol}$ lower than that of the reaction that used a cluster of four $\mathrm{H}_{2} \mathrm{O}$ molecules as the proton acceptor (Scheme 12). Furthermore, Cao et al. [91] reported the remarkable water oxidation activity of a pyrene-modified Co-corrole complex immobilized on carbon supports, which was attributed to the strong noncovalent $\pi-\pi$ interactions between the pyrene moiety and carbon supports. In addition, Cao et al. [92-94] reported that the water oxidation catalytic performance of the Co-corrole complexes was increased by connecting them to carbon nanotubes via covalent conjugated links. Furthermore, the effect of the trans axial ligand of Co-corroles on the water oxidation activity was investigated [95], and it was determined that the axial ligands on the Co centers presented significant effect on the catalytic OER activity and the Co-corroles with electron-donating trans axial ligands were more active. Moreover, Groves et al. indicated that the buffer base in the solution played important roles during both the PCET processes and the $0-0$ bond formation step; in addition, more basic buffer base anions led to lower $0-0$ bond formation energy barriers [96].

Cao et al. reported a cationic Ni-porphyrin (Ni-Por) complex with meso-tetrakis ( $N$-methyl-4-pyridyl) as WOC [97]. The rate-determining $\mathrm{O}-\mathrm{O}$ bond formation step was proposed to occur between the Por-NiIII-O radical and $\mathrm{a}_{2} \mathrm{O}$ molecule nucleophile. The energy barrier of the $\mathrm{O}-\mathrm{O}$ bond formation reaction using acetate anions as proton acceptors was lower than that of a water-cluster induced reaction, and that was similar to the $\mathrm{HO}^{--}-\mathrm{Co}^{\mathrm{III}}$-corrole ${ }^{\bullet+}$-triggered $\mathrm{O}-\mathrm{O}$ bond formation process [90]. Sun et al. [98] also reported a WNA-type 0-0 bond formation mechanism, where a NiII PY5 complex was used to promote water oxidation. Two sequential PCET processes and a subsequent $1 \mathrm{e}^{-}$oxidation reaction formed the key $\mathrm{Ni}^{\mathrm{V}}=\mathrm{O}$ intermediate species, which was subsequently attacked by a $\mathrm{H}_{2} \mathrm{O}$ molecule to form $\mathrm{O}-\mathrm{O}$ bonds. In addition, it was determined that the added $\mathrm{HPO}_{4}{ }^{2-}$ buffer base acted as the proton acceptor during the proposed APT process of the WNA-type O-O bond



Scheme 12. Molecular structure of 15 , and schematic diagram of two different water nucleophilic attack-type $\mathrm{O}-\mathrm{O}$ bond formation transition states using a $\mathrm{H}_{2} \mathrm{O}$ cluster or an acetate anion as the external bases. formation.

Meyer et al. [99] reported that homogeneous $\mathrm{Cu}$ complexes significantly promoted water oxidation, and the simple monomeric [(bpy) $\left.\mathrm{Cu}\left(\mathrm{OH}_{2}\right)_{2}\right]$ complex was proposed as the dominant catalytic species. Subsequently, Lin et al. [100] reported that a Cu-bpy related complex with pendant hydroxyl groups could serve as WOC at much lower potentials than those reported by Meyer et al. Combined experimental data and theoretical results indicated that the 6,6'-dihydroxy-2,2'-bipyridine ligand was redox non-innocent, which was ascribed to the low redox potentials of the mononuclear $\mathrm{Cu}$ complexes. The typical $\mathrm{Cu}^{\mathrm{IV}}$-hydroxyl complex (better described as $\mathrm{L}^{\cdot-}-\mathrm{Cu}^{\mathrm{III}}-\mathrm{OH}$, where $\mathrm{L}$ is the bidentate ligand) was proposed to be the key intermediate to trigger the WNA. The proposed catalytic cycle is presented in Scheme 13. Zhang et al. [101] and Pap et al. [102] proposed similar WNA-type 0-O bond formation pathways. The added buffer base or carbonate anion were determined to act as proton acceptors during the APT process of the WNA-type 0-O bond formation process [103,104].

\subsection{Single-electron transfer WNA}

The concerted typical $2 \mathrm{e}^{-}$reduction of the metal center and O-O bond formation are known to occur during WNA-type reactions. Alternatively, a stepwise single-electron transfer (SET)-WNA mechanism was proposed. Garrido-Barros et al. [105] reported a series of mononuclear $\mathrm{Cu}$ complexes, 17, that contained tetraanionic tetradentate amide ligands as WOCs. The low redox potentials of the $\mathrm{Cu}$ complex couples were ascribed to the good donating capacity of the anionic ligand and redox non-innocent nature of the ligands. The $\mathrm{L} \cdot-\mathrm{Cu}^{\mathrm{III}}-\mathrm{OH}$ complex was treated as the key intermediate to trigger $0-0$ bond formation. Unlike the conventional 2e- WNA-type $0-0$ bond formation, the proposed $0-0$ bond formation was a two-step process: (1) $1 \mathrm{e}^{-}$transfer from the incoming hydroxide anion to the oxidized ligand of $\mathrm{L}^{-}-\mathrm{Cu}^{\text {III-OH }}-\mathrm{OH}$ and (2) the reduction of the $\mathrm{Cu}(\mathrm{III})$ center during the other $1 \mathrm{e}^{-}$transfer process. Llobet et al. [105] labelled this type of $0-0$ bond formation mechanism as SET-WNA. Two consecutive intramolecular SET steps took

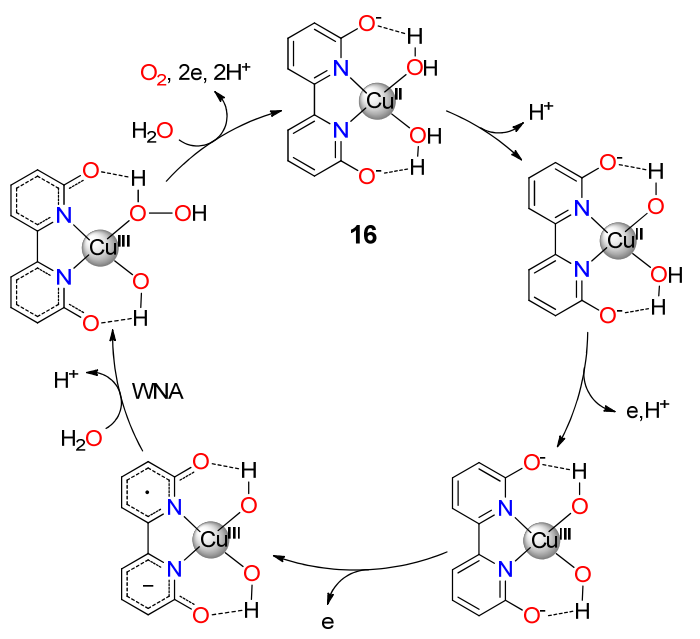

Scheme 13. Molecular structure of $\mathbf{1 6}$ and proposed water oxidation catalytic cycle. 
place to generate the L-Cu-HOOH complex, in which the $\mathrm{HOOH}$ species formed hydrogen bonds with the complex in the absence of direct $\mathrm{Cu}-\mathrm{O}$ bonds. The SET-WNA process is schematically illustrated in Scheme 14.

Sens et al. [106] determined that no typical $\mathrm{Cu}-\mathrm{O}$ bonds were present in the key intermediate that formed between the two ISET processes, instead, the (HO---OH) -- moiety was hydrogen-bonded to the ligand of $\mathrm{L}-\mathrm{Cu}^{\mathrm{III}}$. Therefore, it was estimated that the presence of the transition-metal center able to undergo fast $1 \mathrm{e}^{-}$transfer to the HO---OH moiety and redox-active ligands, and also the facile dissociation of the $\mathrm{M}-\mathrm{OH}$ bonds and ability to form hydrogen bonds between the (HO---OH) ${ }^{--}$moiety and ligands were prerequisites that would enable the SET-WNA O-O bond formation mechanism.

\section{I2M bond formation mechanism}

Radical recombination between two metal-oxo radical species (M-O*) occurs during I2M. That generates a peroxide-bridged M-O-O-M species, and the subsequent oxidation of the $\mathrm{M}-\mathrm{O}-\mathrm{O}-\mathrm{M}$ species generates $\mathrm{O}_{2}$. A direct I2M pathway might be energetically unfavorable and would likely involve a bridging solvent $\mathrm{H}_{2} \mathrm{O}$ molecule. Radical coupling strategies require that the two metal-oxo radicals are convergent. Alternatively, two co-facial high-valent $\mathrm{M}=\mathrm{O}$ species would bind with each other to generate a M-O-O-M species and facilitate the typical $1 \mathrm{e}^{-}$reduction of the metal center.

The $\mu$-oxo bridges of the blue dimer and its derivates are not stable; they could cleave in solution and break down the catalytically active dimeric structures. Llobet et al. [106] reported a $\mathrm{Ru}-\mathrm{Hbpp}$ catalyst $\left(\left[\mathrm{Ru}_{2}\left(\mathrm{OH}_{2}\right)_{2}(\mathrm{bpp})(\mathrm{tpy})_{2}\right]^{2+}(\mathbf{1 8})\right.$, where Hbpp and tpy denote $2,2^{\prime}$-(1H-pyrazole-3,5-diyl)dipyridine and terpyridine, respectively, in which the fragile oxo-bridge was replaced by an aromatic pyrazole-linkage. The water oxidation capability of $\mathbf{1 8}$ was superior to that of the blue dimer because catalyst decomposition was avoided in the absence of the oxo-bridge. In contrast with the blue dimer, the cis-fashion oriented Ru centers and close bimetallic proximity introduced by the rigid pyrazole bridge in $\mathbf{1 8}$ facilitated the I2M-type 0-O bond formation $[106,107]$. In addition, the head-to-head orientations of the two $\mathrm{Ru}=\mathrm{O}$ moieties facilitated the I2M-type 0-0 bond formation (Scheme 15). Baik et al. [107] calculated that

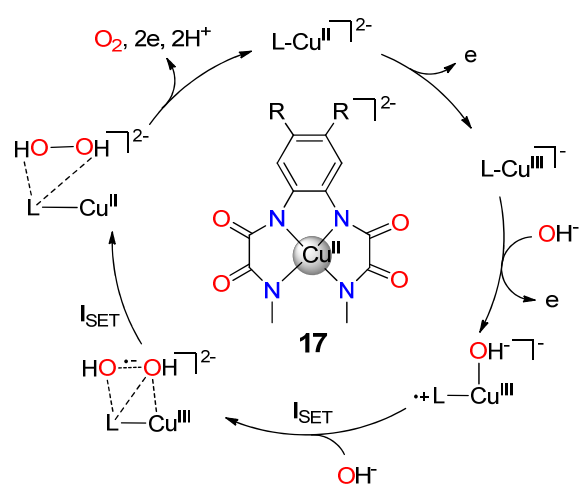

Scheme 14. Molecular structure of 17 , and proposed water oxidation catalytic cycle via single electron transfer (SET)-water nucleophilic attack $\mathrm{O}-\mathrm{O}$ bond formation. the catalytically active species was the $\mathrm{Ru}_{2}{ }^{\mathrm{IV}, \mathrm{IV}}$ intermediate rather than high-valent $\mathrm{Ru}_{2} \mathrm{~V}, \mathrm{IV}$ or $\mathrm{Ru}_{2} \mathrm{~V}, \mathrm{~V}$ species (based on the significantly larger calculated oxidation potentials compared with the experimentally determined ones). Baik et al. [107] investigated both the WNA and I2M O-O bond formation mechanisms, and their theoretical results indicated that the energy barrier of the I2M-type 0-O bond formation was 10.6 $\mathrm{kcal} / \mathrm{mol}$ lower than that of the WNA-type 0-O bond formation. The favored I2M pathway was ascribed to the close bimetallic proximity and strong through-space interaction between the $\mathrm{Ru}^{\mathrm{IV}}-\mathrm{O} \cdot$ radical moieties. Thus, when the active $\mathrm{Ru}^{\mathrm{IV}}-\mathrm{O} \cdot$ species were generated, they immediately coupled to form $\mathrm{O}-\mathrm{O}$ bonds via the I2M pathway. Llobet et al. [108] also studied the trans-fashion oriented binuclear Ru complex with rigid pyrazole bridge, and hypothesized that $\mathrm{O}-\mathrm{O}$ bond formation proceeded via the $\mathrm{I} 2 \mathrm{M}$ pathway between two $\mathrm{Ru}^{\mathrm{IV}}=0$ species.

Tanaka et al. [109,110] introduced redox-active ligands combined with redox-active $\mathrm{Ru}$ centers, and reported a quinone-linked diruthenium complex $\left[\mathrm{Ru}_{2}(\mathrm{OH})_{2}(\mathrm{Q})_{2}(\text { btpyan) }]\right]^{2+}$ (19), where $Q$ and btpyan denote 3,6-di-t-butyl-benzoquinone and 1,8-bis-terpyridyl anthracene, respectively, in which the redox non-innocent quinone moiety was estimated to act as electron reservoir to accommodate the electrons from the metal-to-ligand charge transfer processes. The anthracene bridge was estimated to bring the two Ru halves in close proximity, which subsequently facilitated the intramolecular coupling that triggered the I2M-type 0-0 bond formation [109,110]. Subsequent quantum calculations were conducted to reveal the OER mechanisms. Muckerman et al. [111] theoretically reconfirmed the electron-accommodating role of quinone; moreover, they indicated that the $\mathrm{Ru}$ centers appeared to maintain low oxidation states and the quinone ligands and $\mathrm{H}_{2} \mathrm{O}$ moiety were involved in redox reactions throughout the entire water oxidation catalytic cycle. In addition, $\left[\mathrm{Ru}^{\mathrm{II}} 2(\mathrm{O}--\mathrm{O})^{-}\left(\mathrm{Q}^{-1.5}\right)_{2}(\right.$ btpyan $\left.\left.)\right]\right]^{0}$ was identified as a key intermediate. Baik et al. $[112,113]$ and Tanaka et al. [114] calculated that the ground state of the initial dihydroxo complex should be better represented as open shell singlet, where the unpaired electron was located at one $\mathrm{Ru}^{\mathrm{III}}$ center and the ligand. In addition, it was proposed that the $0-0$ bond formation occurred after the deprotonation reactions [112-114]. Nocera et al. [115] and Berlinguette et al. [116] also reported a related binuclear $\mathrm{Ru}$ complex $\mathbf{2 0}$ that featured a dibenzofuran spacer to preorganize the metal centers in a co-facial arrangement but with elongated bimetallic distance (Scheme 16). In addition, they indicated that the direct I2M-type O-O bond formation was unlikely for the dibenzofuran-orientated binuclear Ru complex; moreover, the significant participation of solvent $\mathrm{H}_{2} \mathrm{O}$ molecules in the $\mathrm{O}-\mathrm{O}$ bond for-

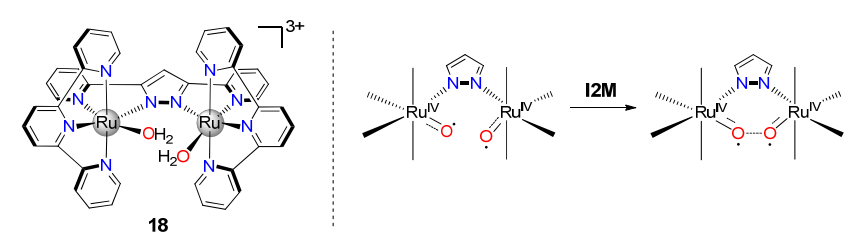

Scheme 15. Molecular structures of 18, and proposed coupling between two metal oxo/oxyl units (I2M)-type 0-0 bond formation mechanism. 




Scheme 16. Molecular structures of 19 and 20, and proposed 19-mediated intramolecular coupling between two metal oxo/oxyl units (I2M)-type $\mathrm{O}-\mathrm{O}$ bond formation mechanism.

mation process was suggested. These findings were ascribed to the elongated bimetallic distance owing to the orientation introduced by the asymmetric dibenzofuran bridge.

The use of negatively charged ligands decreases the oxidation potentials of WOCs. Sun et al. [117] reported a mononuclear $\mathrm{Ru}$ complex $\left[\mathrm{Ru}(\mathrm{bda})(\mathrm{pic})^{2}\right]$ (21) that contained a tetradentate ligand with anionic carboxylate moieties. An atypical seven-coordinated intermediate $\mathrm{Ru}(\mathrm{IV})$ dimeric complex featuring a [ $\left.\mathrm{H}_{2} \mathrm{O}-\mathrm{HO}-\mathrm{H}-\mathrm{OH}-\mathrm{H}_{2} \mathrm{O}\right]^{-}$(simplified as [HOHOH$]^{-}$) bridge was isolated, which indicated that ligand exchange on the octahedral $\mathrm{Ru}$ center was not a prerequisite (Scheme 17). The [HOHOH]- bridge would act as proton channel for the subsequent water oxidation reaction. The $\mathrm{Ru}^{\mathrm{II}}-\mathrm{OH}_{2} \rightarrow \mathrm{Ru}^{\mathrm{III}}-\mathrm{OH}_{2} \rightarrow$ $\mathrm{Ru}^{\mathrm{IV}}-\mathrm{OH} \rightarrow \mathrm{Ru}=\mathrm{O}$ oxidation process was observed. Water oxidation was suggested to be triggered by the formation of the $\mathrm{Ru}^{\mathrm{V}}=\mathrm{O}$ intermediate, and the $\mathrm{O}-\mathrm{O}$ bond formation step involved the I2M coupling of two $\mathrm{Ru}^{\mathrm{V}}=\mathrm{O}$ species. The I2M-favored $\mathrm{O}-\mathrm{O}$ bond formation mechanism was ascribed to the close proximity of the two bimolecular Ru-oxo species owing to the [HOHOH$]^{-}$ bridge. In contrast, the mononuclear six-coordinated Ru complex-mediated O-O bond formation generally favors the WNA pathway [118]. Sun et al. [119] reported a tridentate dicarboxylate ligand-containing mononuclear $\mathrm{Ru}$ complex, [Ru(pdc)(pic)3], where $\mathrm{H}_{2}$ pdc and pic denote 2,6-pyridinedicarboxylic acid and picoline, respectively, which facilitated the picoline- $\mathrm{H}_{2} \mathrm{O}$ ligand exchange and subsequent WNA-type water oxidation.

The rate of the I2M-type $0-0$ bond formation process was
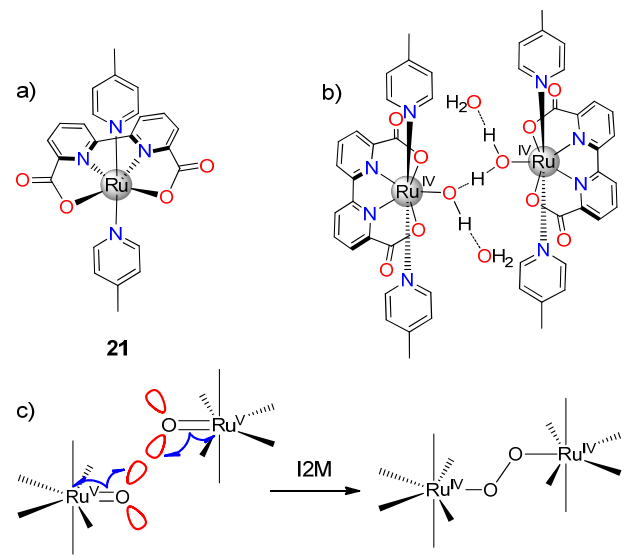

Scheme 17. (a) Molecular structure of 21. (b) Isolated seven-coordinated $\mathrm{Ru}(\mathrm{IV})$ dimer complex with $\left[\mathrm{H}_{2} \mathrm{O}-\mathrm{HO}-\mathrm{H}-\mathrm{OH}-\mathrm{H}_{2} \mathrm{O}\right]$ bridge. (c) Intramolecular coupling between two metal oxo/oxyl units (I2M) 0-0 bond formation mechanism between two seven-coordinated $\mathrm{Ru}^{\mathrm{V}}=\mathrm{O}$ (or $\mathrm{Ru}^{\mathrm{IV}}-\mathrm{O}^{\bullet}$ ) intermediates. significantly increased by the introduction of axial isoquinoline (isoq) ligands, as in [Ru(bda)(isoq) 2 , (22), which were suggested to facilitate the direct $\mathrm{O}-\mathrm{O}$ coupling of two typical $\mathrm{Ru}=\mathrm{V}$ (or $\mathrm{Ru}^{\mathrm{IV}-\mathrm{O}^{\bullet}}$ ) species via the $\pi-\pi$ stacking noncovalent interactions between two isoq moieties (Scheme 18) [120]. Conception et al. [121] performed detailed mechanistic studies on the I2M origins of [Ru(bda)(isoq) $\left.)_{2}\right]$ analogues and revealed that the main contributor to the increase in the reaction rate was entropy, owing to the highly organized transition states. Ahlquist et al. [122] investigated the activation energy of the coupling between two $\mathrm{Ru}^{\mathrm{IV}}-\mathrm{O} \cdot$ radicals. They divided the activation barrier energy into distortion and interaction energy, and their computational analysis results indicated that several aspects, such as solvation, supramolecular properties, and solvent dynamics likely played important roles in the equilibrium between the free typical $\mathrm{Ru}^{\mathrm{V}}=\mathrm{O}$ monomers and $\mathrm{Ru}=\mathrm{V}=\mathrm{O}--\mathrm{O}=\mathrm{Ru}^{\mathrm{V}}$ dimer.

Sun et al. [123] concluded that the dissociation of axial ligands was the major deactivation cause of the monomeric $\mathrm{Ru}$ complexes they analyzed. Furthermore, they investigated the binding affinity of axial ligands and proposed that an axial ligand with high highest occupied molecular orbital energy level could form a highly durable mononuclear $\mathrm{Ru}$ complex that would present remarkable catalytical performance. A shorter $\mathrm{Ru}^{\mathrm{V}}=\mathrm{O}$ distance between two facial monomeric complexes would accelerate the I2M-type water oxidation; this inspired the construction of flexibly bridged binuclear $\mathrm{Ru}$ complexes, which presented excellent water oxidation performance [124].

Masaoka et al. [125] used a pentanuclear Fe complex as WOC. In addition, Liao et al. [126] analyzed the metal oxidation states during the $\mathrm{O}-\mathrm{O}$ bond formation process and determined that the most favorable $\mathrm{O}-\mathrm{O}$ bond formation mechanism should be the direct I2M coupling of two $\mathrm{Fe}^{\mathrm{IV}}-\mathrm{O}$ radicals.

Nocera et al. [115] reported a binuclear Co complex that featured a flexible cavity with two trigonal-bipyramidal scaffolds, which allowed oxo radicals to be brought together and facilitated the I2M-type $\mathrm{O}-\mathrm{O}$ bond formation.

\section{Shifting between WNA and I2M}

Llobet et al. [127] reported a binuclear $\mathrm{Ru}$ complex $\left[\left(\mathrm{py}^{-\mathrm{SO}_{3}}\right)\left(\mathrm{OH}_{2}\right) \mathrm{Ru}(\mu-\mathrm{Mebbp}) \mathrm{Ru}\left(\mathrm{OH}_{2}\right)\left(\mathrm{py}^{\left.\left.-\mathrm{SO}^{3}\right)\right]^{3-}}\right.\right.$ (23) with a planar penta-dentate pyrazole-bridged Mebbp ligand, which separated the bimetallic centers in the equatorial plane. In con-



Scheme 18. Molecular structure of 22 , and $\pi-\pi$ stacking noncovalent interaction between two isoquinoline moieties. 
trast to the bpp-containing $\mathbf{2 4 ,} 23$ was found to mediate the O-O bond formation via the WNA mechanism. The Mebbpligand in $\mathbf{2 3}$ served as bis-meridional scaffold to constrain the bimetallic centers and Mebbp- ligand within the equatorial plane. That generated a very small $\mathrm{Ru}-\mathrm{N}-\mathrm{N}-\mathrm{Ru}$ torsion angle $\left(0.4^{\circ}\right.$ for the acetate-bridged 23 analogue). Conversely, the $\mathrm{Ru}-\mathrm{N}-\mathrm{N}-\mathrm{Ru}$ dihedral angle in bpp-containing $\mathbf{2 4}$ was increased to $25.3^{\circ}$. Consequently, the constraints of the bis-meridional scaffold Mebpp- ligand increased the bimetallic distance, and that reduced the through-space interaction of the two $\mathrm{Ru}-\mathrm{O}$ moieties and shifted the preferred $\mathrm{O}-\mathrm{O}$ bond formation mechanism to WNA. The different $\mathrm{O}-\mathrm{O}$ bond formation mechanisms of $\mathbf{2 3}$ and $\mathbf{2 4}$ demonstrated that the WNA and I2M pathways could be shifted using subtle ligand variations. Thummel et al. [128] reported similar water oxidation active binuclear $\mathrm{Ru}$ complexes featuring rigid planar bis-tridentate polypyridyl-based ligands. The OER was a first-order reaction in respect to the catalyst concentration, which indicated that the two $\mathrm{Ru}$ centers cooperated [25,128]. Less torsion distortions would be expected in the bimetallic centers embedded equational planar, which caused the Ru-Ru distance to increase, and therefore, the $\mathrm{O}-\mathrm{O}$ bond formation was suggested to follow the WNA mechanism (Scheme 19). More recently, Llobet et al. [129] and Meyer et al. [130] reported a bbp-based diruthenium water oxidation complex $\left(\left[\mathrm{Ru}_{2}\left(\mathrm{OH}_{2}\right)_{2}(\mathrm{OAc}-\mathrm{bbp})(\mathrm{py})_{4}\right]^{2+}\right)$ with a carboxylate anchor at the ligand backbone. It was determined that the effect of the backbone anchor on the electronic properties of the diruthenium centers, and consequently the catalytic water oxidation performance, was insignificant. $\mathrm{The} \mathrm{Ru}^{\mathrm{V}}=0$ was reconfirmed as the key intermediate to trigger the WNA-type O-O bond formation processes.

Sun et al. [50] reported a similar mononuclear Ru complex [Ru(bda)(DMSO)(L)] (25), where DMSO denotes dimethyl sulfoxide, with axially coordinated DMSO and imidazole. The WOC simulation demonstrated that the $\mathrm{Ce}^{\mathrm{IV}}$-driven water oxidation was better than the 25-mediated one and the $0-0$ bond formation occurred via an I2M mechanism. A similar seven-coordinated intermediate $\mathrm{Ru}^{\mathrm{IV}}-\mathrm{OH}$ with axial $\mathrm{Ru}^{\mathrm{IV}}-\mathrm{O}$ (DMSO) bond was analyzed. Sun et al. suggested that the smaller collisions between the axial and equatorial ligands favored the I2M-type 0-0 bond formation (Scheme 20). In contrast, the WNA 0-O bond formation pathway was proven to be more favorable when mediated by the monomeric $\mathrm{Ru}$ complex [Ru(pda)(pic) 2] (26), where $\mathrm{H}_{2}$ pda denotes 1,10-phenanthroline-2,9-dicarboxylic acid, which contained a rigid phenanthroline dicarboxylate ligand. The increased collisions of the axial picoline moieties introduced by the confinement of the rigid ligand prevented the two typical $\mathrm{Ru}^{\mathrm{V}}=0$ species from approaching each other, which significantly increased

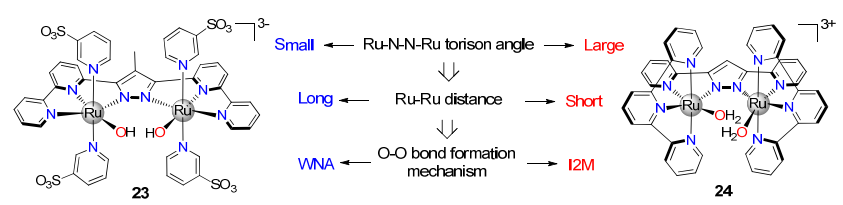

Scheme 19. Schematic diagram of origins of different $0-0$ bond formation mechanism mediated by 23 and 24 .



Scheme 20. Schematic diagram of origins of different $0-0$ bond formation mechanism mediated by 25 and 26.

the energy barrier of the direct I2M-type 0-0 coupling [49].

The changes in substituents in Co-porphyrin complexes can alter the 0-O bond formation mechanism. Sakai et al. [131] proposed that the rate determining step of the water oxidation reaction should proceed via the radical coupling of two CO-oxyl radicals when the substituents of Co-porphyrin complex 27 were less bulky (Scheme 21). However, the WNA-type 0-0 bond formation was suggested for bulky Co-porphyrin complex 28 [132]. In addition, it was suggested that the WNA pathway was preferred for $\mathrm{O}-\mathrm{O}$ bond formation when mononuclear Co complexes with non corrole or porphyrin-related ligands were used as WOCs [133-136].

\section{Other $0-0$ bond formation mechanisms}

In addition to the aforementioned WNA and I2M mechanisms of $\mathrm{O}-\mathrm{O}$ bond formation, three more $\mathrm{O}-\mathrm{O}$ bond formation mechanisms are reviewed in the following sections.

\subsection{IHC and BHC mechanisms}

O-O bond would be directly formed via couplings between two metal-bound hydroxyl groups. For the IHC mechanism, unimolecular dihydroxo coupling is suggested to occur, which leads to the generation of metal-hydroperoxides and their subsequent oxidations would release $\mathrm{O}_{2}$.

Milstein et al. [137] reported a non-aromatic mononuclear $\mathrm{Ru}$ pincer complex $\mathbf{2 9}$, which was determined to consecutively promote the generation of $\mathrm{H}_{2}$ and $\mathrm{O}_{2}$ from $\mathrm{H}_{2} \mathrm{O}$. The pincer complex rapidly reacted with $\mathrm{H}_{2} \mathrm{O}$ and led to ligand aromatization and the formation of a trans hydrido-hydroxo complex. The formed hydrido-hydroxo complex further reacted with $\mathrm{H}_{2} \mathrm{O}$ to generate a cis-dihydroxo complex. $\mathrm{H}_{2}{ }^{17} \mathrm{O}$ and $\mathrm{H}_{2}{ }^{18} \mathrm{O}$ isotopic labelling experiments indicated unequivocally that $\mathrm{H}_{2} \mathrm{O}_{2}$ was released from the dihydroxo intermediate and $\mathrm{O}-\mathrm{O}$ bond for-

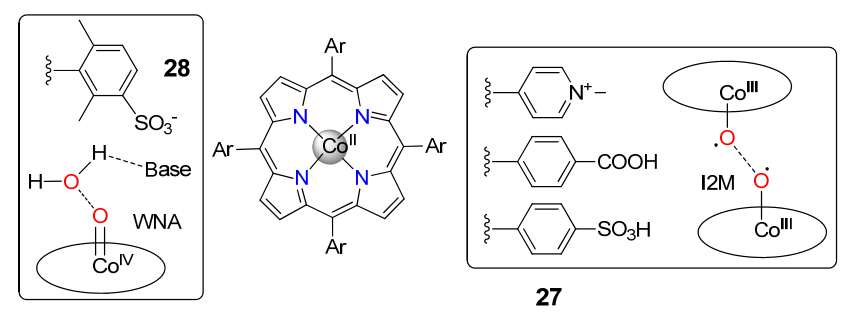

Scheme 21. Molecular structures of 27 and 28, and proposed water nucleophilic attack (WNA) or coupling between two metal oxo/oxyl units (I2M) O-O bond formation mechanisms. 
mation occurred via the IHC mechanism (Scheme 22). The alternative BHC mechanism for 0-0 bond formation was ruled out using isotopic labelling experiments. Hall et al. [138] used time-dependent density functional theory (TD-DFT) calculations to predict that the breaking of the two strong $\mathrm{Ru}-\mathrm{O}$ bonds and formation of the $\mathrm{O}-\mathrm{O}$ bond during this photolytic reaction involved low-energy triplet states and singlet-triplet crossings. In addition, Fang et al. [139] proposed an alternative reaction pathway, in which $\mathrm{H}_{2} \mathrm{O}_{2}$ was not suggested to be an important intermediate for $\mathrm{O}_{2}$ formation. Instead, the formation of triplet $\mathrm{O}_{2}$ molecules consisted of two steps: concerted hydrogen transfer and dehydration. The light-induced OER was determined to be a nonadiabatic process, and the $0-0$ bonds was formed via unimolecular metal-oxo coupling.

Crabtree et al. [140] developed a single-site Ir complex 30 with a C,C-chelating $\mathrm{N}$-heterocyclic carbene (NHC) ligand (Scheme 23). The singlet NHC was proven to possess good $\sigma$-donating ability to stabilize high-valent metal centers, which would subsequently result in low oxidation potentials and the high stability of the Ir ${ }^{\mathrm{IV}}{ }^{-}$-intermediate. A series of sequential $1 \mathrm{e}^{-}$ oxidations were observed during water oxidation, and a BHC-type 0-0 bond formation mechanism was estimated because the kinetic survey established that the order of the water oxidation reaction was close to 2 . In contrast, Hetterscheid et al. [141] reported a $\mathrm{Me}_{2}-\mathrm{NHC}$ based mononuclear Ir complex 31 for the water oxidation reaction. An incubation process was observed when the complex generated the active Ir-aqua catalyst. The excellent water oxidation rate of $\mathbf{3 1}$ was ascribed to the electron-donating normal carbene and open coordination sites of the aqua species. A mononuclear IHC-type 0-0 bond formation pathway was proposed for the water oxidation reaction $[141,142]$.

Lu et al. [141] reported a robust macrocyclic mononuclear $\mathrm{Ni}$ complex 32 as WOC [143]. Significant isomerization was suggested to occur between the trans-bis(aqua) $\mathrm{NiIII}$ complex and cis-bis(aqua) NiIII species; in addition, the cis isomer was proposed to be the active catalyst form. The formed cis-Niv-bis(hydroxyl) could trigger $\mathrm{HO}-\mathrm{OH}$ coupling on the $\mathrm{Ni}$ center. Theoretical studies revealed that the energy barrier of the IHC-type $\mathrm{O}-\mathrm{O}$ bond formation was significantly lower than

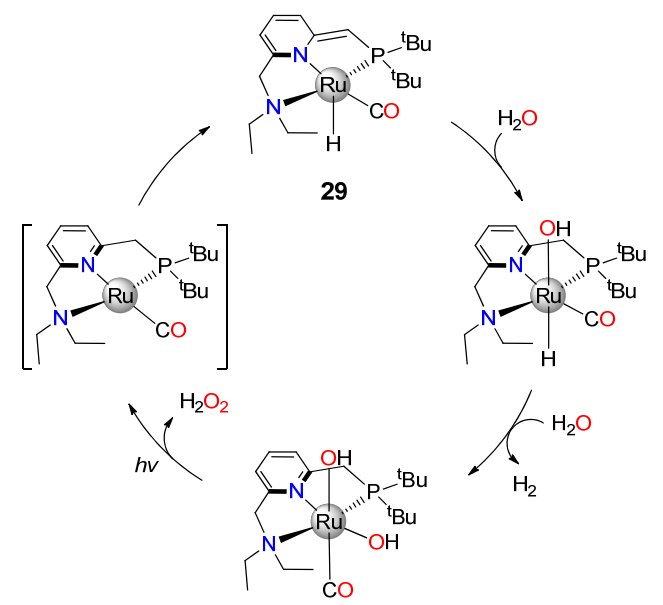

Scheme 22. Molecular structure of 29, and proposed mechanism for the formation of $\mathrm{H}_{2}$ and $\mathrm{O}_{2}$ from $\mathrm{H}_{2} \mathrm{O}$.

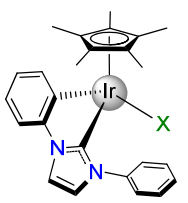

30

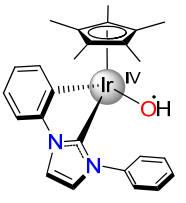

31

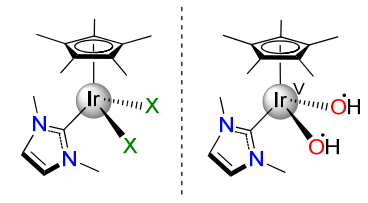

31
Scheme 23. Molecular structures of $\mathbf{3 0}$ and $\mathbf{3 1}$ and their respective key intermediates for hydroxyl coupling $0-0$ bond formation.

that of the WNA-type 0-O bond formation. The proposed catalytic cycle is illustrated in Scheme 24. Similar IHC-type 0-O bond formation mechanisms were reported in other papers [144,145].

Recently, Cao et al. [146] reported low overpotential water oxidation at neutral $\mathrm{pH}$ catalyzed by a $\mathrm{Cu}$ complex with tetrakis(4- $N$-methylpyridyl)porphyrin. Their experimental results suggested the 1e-oxidized species of $\mathrm{Cu}^{\mathrm{II}}$-porphyrin triggered the $\mathrm{O}-\mathrm{O}$ bond formation reaction, and the $\mathrm{BHC}$ of the


as the $\mathrm{O}-\mathrm{O}$ bond formation mechanism. This reaction mechanism allowed for this $\mathrm{Cu}$ porphyrin to catalyze water oxidation at neutral pH values and very low overpotentials. Furthermore, at acidic $\mathrm{pH}$ values, a $\mathrm{H}_{2} \mathrm{O}_{2}$ intermediate was detected. It is unprecedented that this $\mathrm{Cu}$ porphyrin could catalyze the $4 \mathrm{e}^{-}$water oxidation to produce $\mathrm{O}_{2}$ in neutral solutions and catalyze the $2 \mathrm{e}^{-}$water oxidation to produce $\mathrm{H}_{2} \mathrm{O}_{2}$ in acidic solutions.

\subsection{IOC mechanism}

0-0 bond formation could also take place via the direct coupling between two unimolecular metal-oxo species. Smith et al. [147] reported a mononuclear cis-aqua Mn complex 33 with $t$-Bu-substituted pyridinophane ligands, which could mediate water oxidation and generate $\mathrm{O}_{2}$. Baik et al. [148] proposed that a MnV-bis(oxo) species was involved in the $\mathrm{O}-0$ bond formation via the IOC mechanism (Scheme 25). The energy barrier differences between the WNA- and IOC-type 0-O bond formation pathways were further investigated by Liao et al. [149], and the

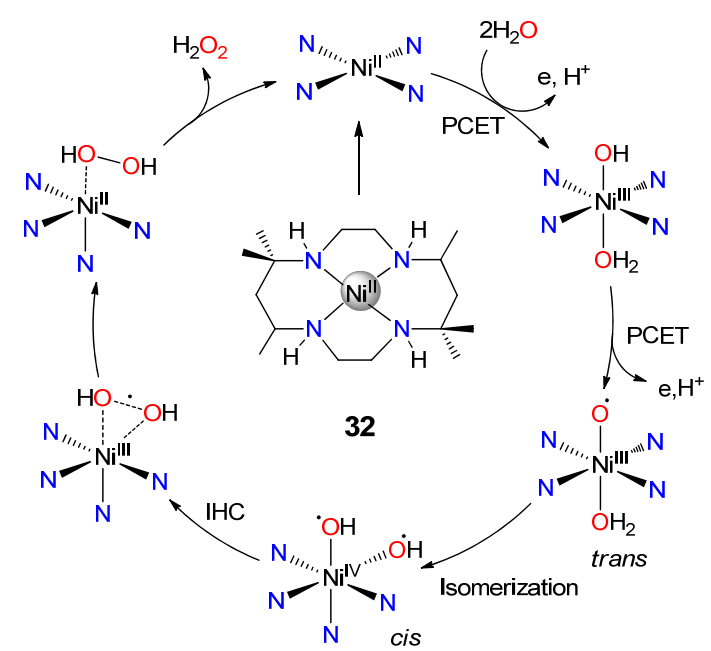

Scheme 24. Molecular structure of 32 and the proposed catalytic cycle of water oxidation. 


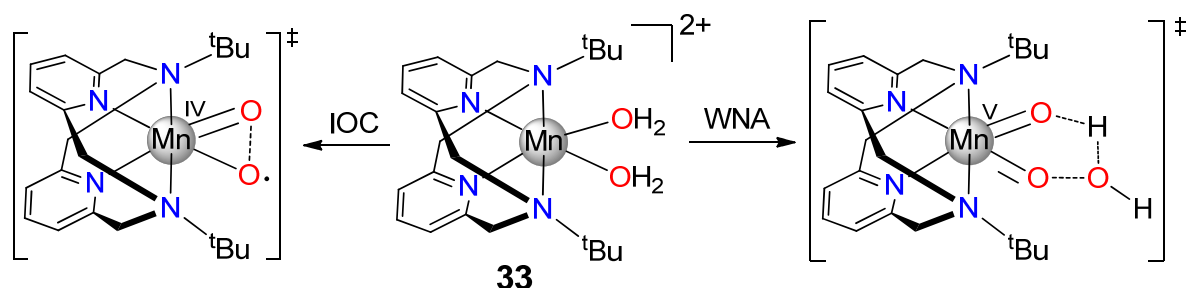

Scheme 25. Molecular structure of 33 and the two different O-O bond formation mechanisms of WNA and IOC.

calculated results indicated that the energy barrier of the WNA-type $0-0$ bond formation was $0.7 \mathrm{kcal} / \mathrm{mol}$ lower than that of IOC mechanism. For the slightly favored WNA pathway, the $\mathrm{Mn} V=0$ species was nucleophilically attacked by a $\mathrm{H}_{2} \mathrm{O}$ molecule and the other oxo moiety acted as internal base to abstract a proton from the coming $\mathrm{H}_{2} \mathrm{O}$ molecule.

Zhang et al. [150] reported the electrocatalytic water oxidation using a binuclear naphthyridine-bridged $\mathrm{Cu}$ complex 34 in neutral aqueous solution. The initial $\mathrm{H}_{2} \mathrm{O}-\mathrm{Cu}^{\mathrm{II}}-\mathrm{OH}-\mathrm{Cu}^{\mathrm{II}}$ complex was found to undergo two consecutive PCET processes to generate $\mathrm{HO}-\mathrm{Cu}^{\mathrm{III}}-\mathrm{OH}-\mathrm{Cu}^{\mathrm{II}}$ and $\mathrm{HO}-\mathrm{Cu}^{\mathrm{III}}-\mathrm{O}-\mathrm{Cu}^{\mathrm{III}}$. Subsequently, direct O-O bond formation occurred via the IOC between the $\mathrm{Cu}^{\mathrm{III}}-\mathrm{O}(\mathrm{H})$ species and bridging $\mu$-oxo synchronously with the intramolecular proton transfer from the CuIII-bound hydroxyl to the uncoordinated pyridine moiety (Scheme 26). Conversely, the energy barrier of the conventional WNA-type 0-0 bond formation triggered by the highly oxidized $\mathrm{Cu}^{\mathrm{IV}}=\mathrm{O}$ intermediate was significantly higher. DFT calculations suggested that the O-O bond formation occurred via a direct IOC mechanism rather than the WNA of the high-valent $\mathrm{Cu}^{\mathrm{IV}}=0$ moiety.

Recently, Hartzler et al. [151] synthesized a $\left[\mathrm{Ru}^{\mathrm{II}}(\mathrm{bpy})_{2}(\mathrm{bpy}-\mathrm{NO})\right]^{2+}$ complex and subsequently proposed a new $\mathrm{O}-\mathrm{O}$ bond formation pathway via the radical coupling of the metal- and ligand-based radicals. The authors calculated that the energy barrier of the intramolecular $0-0$ bond formation between $\mathrm{Ru}^{\mathrm{IV}}-\mathrm{O} \cdot$ and the ligand based radical (L-NO•+) was significantly lower than that of WNA pathway triggered by the high-valent $\mathrm{Ru}^{\mathrm{V}}=\mathrm{O}$ intermediate. Computational analysis revealed that the overpotential of the formation of the $\mathrm{Ru}^{\mathrm{IV}}$-L-NO ${ }^{+}+$radical was lower than that of the formation of the $\mathrm{L}-\mathrm{Ru}^{\mathrm{V}}=\mathrm{O}$ intermediate.

\subsection{RI mechanism}

Tolman et al. [152] observed the reversible $0-0$ bond formation between $\mathrm{Cu}_{2}{ }^{\mathrm{III}, \mathrm{III}}-\mathrm{bis}(\mu$-oxo $)$ and $\mathrm{Cu}_{2}{ }^{\mathrm{IIII}}-\left(\mu-\mathrm{O}_{2}\right)$ species,

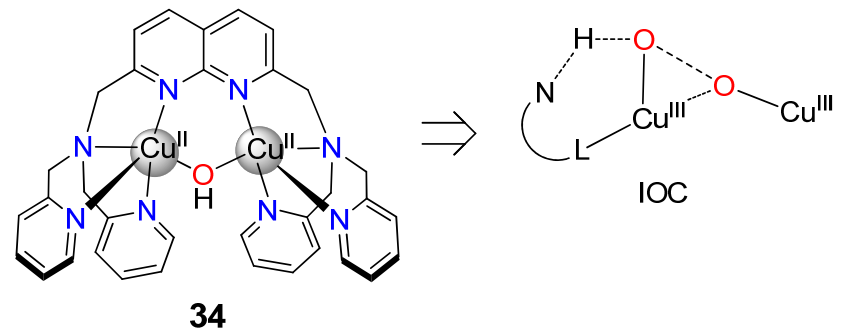

Scheme 26. Molecular structure of $\mathbf{3 4}$ and the proposed 0-0 bond formation mechanism via an IOC mechanism. which elucidated the $0-0$ bond formation mechanism via the RI pathway. Emmons et al. [153] reported a $\mathrm{Cu}$ dimer bearing two $\mu$-hydroxyl bridges, which mediated electrocatalytic water oxidation. The $\mathrm{O}-\mathrm{O}$ bond formation mechanism disfavored single-site pathways. A large kinetic isotope value suggests that the PCET during the initial oxidation was the rate-determining step. The oxidation of the $\mathrm{Cu}_{2} \mathrm{I}, \mathrm{II}-(\mu-\mathrm{OH})_{2}$ generated $\mu$-oxo-bridged $\mathrm{Cu}_{2}{ }^{\mathrm{III}, \mathrm{III}}$ species without the formation of $\mathrm{Cu}^{\mathrm{III}-\mathrm{O}}$ or $\mathrm{Cu}^{\mathrm{IV}}=\mathrm{O}$ species. Subsequently, the $\mathrm{O}-\mathrm{O}$ bond formation mechanisms were investigated, and DFT calculations revealed that energy barrier of the $\mathrm{O}-\mathrm{O}$ bond formation via the $\mathrm{RI}$ mechanism was similar to that of the $0-0$ formation process that occurred via the nucleophilic attack of a $\mathrm{H}_{2} \mathrm{O}$ molecule on the $\mu$-oxo bridge (Scheme 27). Thus, the RI O-O bond formation pathway was demonstrated to be feasible particularly for redox-active metal complex dimers with fragile facial bis( $\mu$-oxo) linkages between bimetallic centers.

\section{Concluding remarks}

In this study, two popular $\mathrm{O}-\mathrm{O}$ bond formation mechanisms: WNA and I2M, and four other mechanisms, viz. BHC, IHC, IOC, and RI, were reviewed.

The sequence of oxidations and/or PCET processes occurred to form high-valent metal-oxo intermediates, which triggered the WNA to form metal-hydroperoxide species while undergoing the typical $2 \mathrm{e}^{-}$reduction of the metal center. In addition, the $\mathrm{O}-\mathrm{O}$ bond formation could occur via the two-step consecutive $1 \mathrm{e}^{-}$transfers to generate metal-hydroperoxide species. The traditional nucleophile species for WNA is a $\mathrm{H}_{2} \mathrm{O}$ molecule, but hydroxide anions and other dissociative anions could also serve as nucleophile species. For the WNA-type 0-O bond formation process, APT with 0 -atom transfer to the oxo terminal occurs together with proton transfer to the base. The base species could be intramolecular metal-oxo species, $\mathrm{H}_{2} \mathrm{O}$ cluster, anions in the solution, or added buffer base. The base species involved in the APT process significantly affect the en-

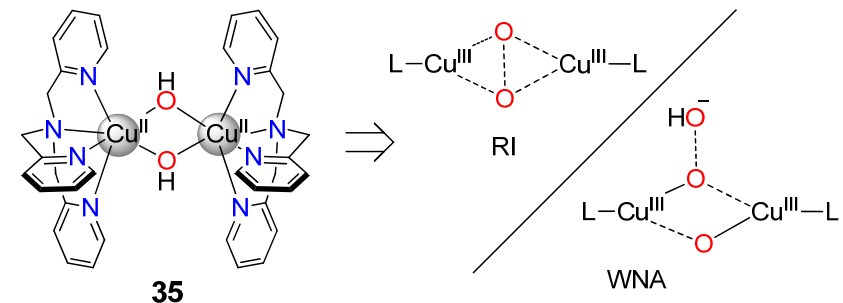

Scheme 27. Molecular structure of 35 and the proposed $0-0$ bond formation mechanism via either a RI or a WNA strategy. 
ergy barrier of the $\mathrm{O}-\mathrm{O}$ bond formation process. Typically, more basic proton acceptors decrease the energy barrier of $\mathrm{O}-\mathrm{O}$ bond formation. Ligands with more pronounced $\sigma$-donating nature or anionic origin decrease the redox potentials of metal-oxygen species, which is beneficial for the generation of high-valent metal-oxo intermediates. The highly oxidized metal-oxo species were typically better described as radicaloids during DFT calculation studies. Despite of extensive experimental and theoretical studies, many uncertainties remain in the identification of the key metal-oxo intermediates, and determination of base species during the APT process of O-O bond formation, which require further systematic mechanistic investigations.

For the I2M mechanism, the intermolecular coupling between two metal-oxo radicals requires that the head-to-head radicals converge and feature small bimetallic distance and strong through-space interaction. The $\mathrm{O}-\mathrm{O}$ bond formation mechanism of metal complexes with flexible equatorial coordination planar for seven-coordination and small steric hindrance between mononuclear halves was estimated to be I2M. The confinement and collisions of ligands were found to change the bimetallic distance, which consequently altered the $0-0$ bond formation mechanisms.

metal-hydroxyl coupling also resulted in $0-0$ bond formation. Typically, IHC and BHC processes do not generate highly oxidized metal-oxo species, which consequently results in the relatively lower $\mathrm{O}-\mathrm{O}$ bond formation barrier than that of the WNA mechanism. Experimental evidence of $\mathrm{O}-\mathrm{O}$ bond formation via IOC and RI was scarce, and both mechanisms were estimated to be feasible when the intramolecular metal-oxo terminals were in close proximity, and more importantly, the $\mathrm{O}-\mathrm{M}-\mathrm{O}$ angles were small (here $\mathrm{M}$ denotes the metal center).

The 0-0 bond formation mechanisms have not been completely elucidated. For example, the identifications of the metal oxidation states of the key metal-oxygen species and the origins triggered different $\mathrm{O}-\mathrm{O}$ bond formation mechanisms. In addition, the lack of direct experimental evidences rendered the mechanistic investigations more difficult but meaningful. The elucidation of the key $\mathrm{O}-\mathrm{O}$ bond formation process is beneficial for the practical applications of industrial water splitting, and use of clean energy.

\section{References}

[1] J. Barber, Chem. Soc. Rev., 2009, 38, 185-196.

[2] J. P. McEvoy, G. W. Brudvig, Chem. Rev., 2006, 106, 4455-4483.

[3] E. M. Sproviero, J. A. Gascón, J. P. McEvoy, G. W. Brudvig, V. S. Batista, Coord. Chem. Rev., 2008, 252, 395-415.

[4] E. M. Sproviero, J. A. Gascón, J. P. McEvoy, G. W. Brudvig, V. S. Batista, J. Am. Chem. Soc., 2008, 130, 3428-3442.

[5] P. E. M. Siegbahn, Chem.-Eur. J., 2006, 12, 9217-9227.

[6] P. E. M. Siegbahn, Biochim. Biophys. Acta, 2013, 1827, 1003-1019.

[7] R. Z. Liao, P. E. M. Siegbahn, ChemSusChem, 2017, 10, 4236-4263.

[8] M. D. Kärkäs, O. Verho, E. V. Johnston, B. Åkermark, Chem. Rev., 2014, 114, 11863-12001.

[9] B. M. Hunter, H. B. Gray, A. M. Müller, Chem. Rev., 2016, 116, 14120-14136.

[10] L. Huang, Y. Zou, D. Chen, S. Wang, Chin. J. Catal., 2019, 40, 1822-1840.

[11] P. Li, W. Chen, Chin. J. Catal., 2019, 40, 4-22.

[12] J. J. Concepcion, J. W. Jurss, M. K. Brennaman, P. G. Hoertz, A. O. T. Patrocinio, N. Y. Murakami Iha, J. L. Templeton, T. J. Meyer, Acc. Chem. Res., 2009, 42, 1954-1965.

[13] D. J. Wasylenko, R. D. Palmer, C. P. Berlinguette, Chem. Commun., 2013, 49, 218-227.

[14] X. Sala, S. Maji, R. Bofill, J. García-Antón, L. Escriche, A. Llobet, Acc. Chem. Res., 2014, 47, 504-516.

[15] J. D. Blakemore, R. H. Crabtree, G. W. Brudvig, Chem. Rev., 2015, $115,12974-13005$.

[16] L. Duan, L. Wang, F. Li, F. Li, L. Sun, Acc. Chem. Res., 2015, 48, 2084-2096.

[17] W. Zhang, W. Lai, R. Cao, Chem. Rev., 2017, 117, 3717-3797.

[18] T. Kikuchi, K. Tanaka, Eur. J. Inorg. Chem., 2014, 2014, 607-618.

[19] A. R. Parent, K. Sakai, ChemSusChem, 2014, 7, 2070-2080.

[20] H. Lei, X. Li, J. Meng, H. Zheng, W. Zhang, R. Cao, ACS Catal., 2019 , 9, 4320-4344.

[21] S. W. Gersten, G. J. Samuels, T. J. Meyer, J. Am. Chem. Soc., 1982, 104, 4029-4030.

[22] X. Yang, M.-H. Baik, J. Am. Chem. Soc., 2006, 128, 7476-7485.

[23] J. L. Cape, J. K. Hurst, J. Am. Chem. Soc., 2008, 130, 827-829.

[24] E. L. Lebeau, S. A. Adeyemi, T. J. Meyer, Inorg. Chem., 1998, 37,

\section{Graphical Abstract}

Chin. J. Catal., 2021, 42: 1253-1268 doi: 10.1016/S1872-2067(20)63681-6

\section{$0-0$ bond formation mechanisms during the oxygen evolution reaction over synthetic molecular catalysts}

Xue-Peng Zhang, Hong-Yan Wang, Haoquan Zheng, Wei Zhang,

Rui Cao*

Shaanxi Normal University

The $0-0$ bond formation mechanisms for water oxidation catalyzed by molecular transition metal catalysts are reviewed. The evolutions of metal-oxo species, water nucleophilic attack and metal-oxo radical couplings of $\mathrm{O}-\mathrm{O}$ bond formation mechanisms


are focused. 
6476-6484.

[25] R. Zong, R. P. Thummel, J. Am. Chem. Soc., 2005, 127, 12802-12803.

[26] H.-W. Tseng, R. Zong, J. T. Muckerman, R. Thummel, Inorg. Chem., 2008, 47, 11763-11773.

[27] N. Kaveevivitchai, L. Kohler, R. Zong, M. El Ojaimi, N. Mehta, R. P. Thummel, Inorg. Chem., 2013, 52, 10615-10622.

[28] J. J. Concepcion, J. W. Jurss, J. L. Templeton, T. J. Meyer, J. Am. Chem. Soc., 2008, 130, 16462-16463.

[29] S. Masaoka, K. Sakai, Chem. Lett., 2009, 38, 182-183.

[30] D. J. Wasylenko, C. Ganesamoorthy, B. D. Koivisto, M. A. Henderson, C. P. Berlinguette, Inorg. Chem., 2010, 49, 2202-2209.

[31] D. J. Wasylenko, C. Ganesamoorthy, M. A. Henderson, B. D. Koivisto, H. D. Osthoff, C. P. Berlinguette, J. Am. Chem. Soc., 2010, 132, 16094-16106.

[32] J. J. Concepcion, J. W. Jurss, M. R. Norris, Z. Chen, J. L. Templeton, T. J. Meyer, Inorg. Chem., 2010, 49, 1277-1279.

[33] X. Sala, M. Z. Ertem, L. Vigara, T. K. Todorova, W. Chen, R. C. Rocha, F. Aquilante, C. J. Cramer, L. Gagliardi, A. Llobet, Angew. Chem. Int. Ed., 2010, 49, 7745-7747.

[34] M. Yoshida, S. Masaoka, K. Sakai, Chem. Lett., 2009, 38, 702-703.

[35] B. Radaram, J. A. Ivie, W. Mangkheimayum Singh, R. M. Grudzien, J. H. Reibenspies, C. E. Webster, X. Zhao, Inorg. Chem., 2011, 50, 10564-10571.

[36] L. Bernet, R. Lalrempuia, W. Ghattas, H. Mueller-Bunz, L. Vigara, A. Llobet, M. Albrecht, Chem. Commun., 2011, 47, 8058-8060.

[37] M. D. Kärkäs, Y.-Y. Li, P. E. M. Siegbahn, R.-Z. Liao, B. Åkermark, Inorg. Chem., 2018, 57, 10881-10895.

[38] M. D. Kärkäs, T. Åkermark, E. V. Johnston, S. R. Karim, T. M. Laine, B.-L. Lee, T. Åkermark, T. Privalov, B. Åkermark, Angew. Chem. Int. Ed., 2012, 51, 11589-11593.

[39] M. D. Kärkäs, T. Åkermark, H. Chen, J. Sun, B. Åkermark, Angew. Chem. Int. Ed., 2013, 52, 4189-4193.

[40] R. Matheu, M. Z. Ertem, J. Benet-Buchholz, E. Coronado, V. S. Batista, X. Sala, A. Llobet, J. Am. Chem. Soc., 2015, 137, 10786-10795.

[41] R. Matheu, M. Z. Ertem, M. Pipelier, J. Lebreton, D. Dubreuil, J. Benet-Buchholz, X. Sala, A. Tessier, A. Llobet, ACS Catal., 2018, 8, 2039-2048.

[42] M. V. Sheridan, B. D. Sherman, S. L. Marquard, Z. Fang, D. L. Ashford, K.-R. Wee, A. S. Gold, L. Alibabaei, J. A. Rudd, M. K. Coggins, T. J. Meyer, J. Phys. Chem. C, 2015, 119, 25420-25428.

[43] J. J. Concepcion, M.-K. Tsai, J. T. Muckerman, T. J. Meyer, J. Am. Chem. Soc., 2010, 132, 1545-1557.

[44] Z. Chen, J. J. Concepcion, X. Hu, W. Yang, P. G. Hoertz, T. J. Meyer, Proc. Natl. Acad. Sci. USA, 2010, 107, 7225-7229.

[45] Z. Chen, J. J. Concepcion, H. Luo, J. F. Hull, A. Paul, T. J. Meyer, J. Am. Chem. Soc., 2010, 132, 17670-17673.

[46] D. E. Polyansky, J. T. Muckerman, J. Rochford, R. Zong, R. P. Thummel, E. Fujita, J. Am. Chem. Soc., 2011, 133, 14649-14665.

[47] L.-P. Wang, Q. Wu, T. Van Voorhis, Inorg. Chem., 2010, 49, 4543-4553.

[48] L. Vigara, M. Z. Ertem, N. Planas, F. Bozoglian, N. Leidel, H. Dau, M. Haumann, L. Gagliardi, C. J. Cramer, A. Llobet, Chem. Sci., 2012, 3 , 2576-2586.

[49] L. Tong, L. Duan, Y. Xu, T. Privalov, L. Sun, Angew. Chem. Int. Ed., 2011, 50, 445-449.

[50] L. Wang, L. Duan, B. Stewart, M. Pu, J. Liu, T. Privalov, L. Sun, J. Am. Chem. Soc., 2012, 134, 18868-18880.

[51] T. Privalov, B. Åkermark, L. Sun, Chem.-Eur. J, 2011, 17, 8313-8317.

[52] L. Tong, A. K. Inge, L. Duan, L. Wang, X. Zou, L. Sun, Inorg. Chem., 2013, 52, 2505-2518.
[53] A. Kimoto, K. Yamauchi, M. Yoshida, S. Masaoka, K. Sakai, Chem. Commun., 2012, 48, 239-241.

[54] M. Murakami, D. Hong, T. Suenobu, S. Yamaguchi, T. Ogura, S. Fukuzumi, J. Am. Chem. Soc., 2011, 133, 11605-11613.

[55] J. M. de Ruiter, R. L. Purchase, A. Monti, C. J. M. van der Ham, M. P. Gullo, K. S. Joya, M. D’Angelantonio, A. Barbieri, D. G. H. Hetterscheid, H. J. M. de Groot, F. Buda, ACS Catal., 2016, 6, 7340-7349.

[56] X. Lin, X. Hu, J. J. Concepcion, Z. Chen, S. Liu, T. J. Meyer, W. Yang, Proc. Natl. Acad. Sci. USA, 2012, 109, 15669-15672.

[57] R. Kang, J. Yao, H. Chen, J. Chem. Theory Comput., 2013, 9, 1872-1879.

[58] N. D. McDaniel, F. J. Coughlin, L. L. Tinker, S. Bernhard, J. Am. Chem. Soc., 2008, 130, 210-217.

[59] L. Vilella, P. Vidossich, D. Balcells, A. Lledós, Dalton Trans., 2011, 40, 11241-11247.

[60] J. F. Hull, D. Balcells, J. D. Blakemore, C. D. Incarvito, O. Eisenstein, G. W. Brudvig, R. H. Crabtree, J. Am. Chem. Soc., 2009, 131, 8730-8731.

[61] J. D. Blakemore, N. D. Schley, D. Balcells, J. F. Hull, G. W. Olack, C. D. Incarvito, O. Eisenstein, G. W. Brudvig, R. H. Crabtree, J. Am. Chem. Soc., 2010, 132, 16017-16029.

[62] A. Bucci, G. Menendez Rodriguez, G. Bellachioma, C. Zuccaccia, A. Poater, L. Cavallo, A. Macchioni, ACS Catal., 2016, 6, 4559-4563.

[63] R.-Z. Liao, P. E. M. Siegbahn, ACS Catal., 2014, 4, 3937-3949.

[64] N. Wang, H. Zheng, W. Zhang, R. Cao, Chin. J. Catal., 2018, 39, 228-244.

[65] M. W. Kanan, D. G. Nocera, Science, 2008, 321, 1072-1075.

[66] A. Singh, L. Spiccia, Coord. Chem. Rev., 2013, 257, 2607-2622.

[67] Y. Gao, J. Liu, M. Wang, Y. Na, B. Åkermark, L. Sun, Tetrahedron, 2007, 63, 1987-1994.

[68] T. Privalov, L. Sun, B. Åkermark, J. Liu, Y. Gao, M. Wang, Inorg. Chem., 2007, 46, 7075-7086.

[69] Y. Gao, T. Åkermark, J. Liu, L. Sun, B. Åkermark, J. Am. Chem. Soc., 2009, 131, 8726-8727.

[70] R. Gupta, T. Taguchi, B. Lassalle-Kaiser, E. L. Bominaar, J. Yano, M. P. Hendrich, A. S. Borovik, Proc. Natl. Acad. Sci. USA, 2015, 112, 5319-5324.

[71] R. Z. Liao, M. D. Karkas, B.-L. Lee, B. Aakermark, P. E. M. Siegbahn, Inorg. Chem., 54, 342-351.

[72] R.-Z. Liao, P. E. M. Siegbahn, J. Catal., 2017, 354, 169-181.

[73] W. C. Ellis, N. D. McDaniel, S. Bernhard, T. J. Collins, J. Am. Chem. Soc., 2010, 132, 10990-10991.

[74] J. L. Fillol, Z. Codolà, I. Garcia-Bosch, L. Gómez, J. J. Pla, M. Costas, Nat. Chem., 2011, 3, 807-813.

[75] Z. Codolà, L. Gómez, S. T. Kleespies, L. Que Jr, M. Costas, J. Lloret-Fillol, Nat. Commun., 2015, 6, 5865.

[76] W. A. Hoffert, M. T. Mock, A. M. Appel, J. Y. Yang, Eur. J. Inorg. Chem., 2013, 2013, 3846-3857.

[77] D. Hong, S. Mandal, Y. Yamada, Y.-M. Lee, W. Nam, A. Llobet, S. Fukuzumi, Inorg. Chem., 2013, 52, 9522-9531.

[78] G. Panchbhai, W. M. Singh, B. Das, R. T. Jane, A. Thapper, Eur. J. Inorg. Chem., 2016, 2016, 3262-3268.

[79] B. Yang, Q.-Q. Yang, X. Jiang, B. Chen, C.-H. Tung, L.-Z. Wu, Chem. Commun., 2017, 53, 9063-9066.

[80] M. K. Coggins, M.-T. Zhang, A. K. Vannucci, C. J. Dares, T. J. Meyer, J. Am. Chem. Soc., 2014, 136, 5531-5534.

[81] C. Panda, J. Debgupta, D. Díaz Díaz, K. K. Singh, S. Sen Gupta, B. B. Dhar, J. Am. Chem. Soc., 2014, 136, 12273-12282.

[82] M. Z. Ertem, L. Gagliardi, C. J. Cramer, Chem. Sci., 2012, 3, 1293-1299.

[83] R.-Z. Liao, X.-C. Li, P. E. M. Siegbahn, Eur. J. Inorg. Chem., 2014, 2014, 728-741. 
[84] W.-P. To, T. Wai-Shan Chow, C.-W. Tse, X. Guan, J.-S. Huang, C.-M. Che, Chem. Sci., 2015, 6, 5891-5903.

[85] Y.-Y. Li, L.-P. Tong, R.-Z. Liao, Inorg. Chem., 2018, 57, 4590-4601.

[86] D. K. Dogutan, R. McGuire, D. G. Nocera, J. Am. Chem. Soc., 2011, 133, 9178-9180.

[87] M. Z. Ertem, C. J. Cramer, Dalton Trans., 2012, 41, 12213-12219.

[88] W. Lai, R. Cao, G. Dong, S. Shaik, J. Yao, H. Chen, J. Phys. Chem. Lett., 2012, 3, 2315-2319.

[89] H. Sun, Y. Han, H. Lei, M. Chen, R. Cao, Chem. Commun., 2017, 53, 6195-6198.

[90] H. Lei, A. Han, F. Li, M. Zhang, Y. Han, P. Du, W. Lai, R. Cao, Phys. Chem. Chem. Phys., 2014, 16, 1883-1893.

[91] H. Lei, C. Liu, Z. Wang, Z. Zhang, M. Zhang, X. Chang, W. Zhang, R. Cao, ACS Catal., 2016, 6, 6429-6437.

[92] X. Li, H. Lei, J. Liu, X. Zhao, S. Ding, Z. Zhang, X. Tao, W. Zhang, W. Wang, X. Zheng, R. Cao, Angew. Chem., Int. Ed., 2018, 57, 15070-15075.

[93] H. Li, X. Li, H. Lei, G. Zhou, W. Zhang, R. Cao, ChemSusChem, 2019, 12, 801-806.

[94] L. Xie, X. Li, B. Wang, J. Meng, H. Lei, W. Zhang, R. Cao, Angew. Chem. Int. Ed., 2019, 58, 18883-18887.

[95] L. Xu, H. Lei, Z. Zhang, Z. Yao, J. Li, Z. Yu, R. Cao, Phys. Chem. Chem. Phys., 2017, 19, 9755-9761.

[96] D. Wang, J. T. Groves, Proc. Natl. Acad. Sci. USA, 2013, 110, 15579-15584.

[97] Y. Han, Y. Wu, W. Lai, R. Cao, Inorg. Chem., 2015, 54, 5604-5613.

[98] L. Wang, L. Duan, R. B. Ambre, Q. Daniel, H. Chen, J. Sun, B. Das, A. Thapper, J. Uhlig, P. Dinér, L. Sun, J. Catal., 2016, 335, 72-78.

[99] S. M. Barnett, K. I. Goldberg, J. M. Mayer, Nat. Chem., 2012, 4, 498-502.

[100] T. Zhang, C. Wang, S. Liu, J.-L. Wang, W. Lin, J. Am. Chem. Soc., 2014, 136, 273-281.

[101] M.-T. Zhang, Z. Chen, P. Kang, T. J. Meyer, J. Am. Chem. Soc., 2013, 135, 2048-2051.

[102] J. S. Pap, Ł. Szyrwiel, D. Srankó, Z. Kerner, B. Setner, Z. Szewczuk, W. Malinka, Chem. Commun., 2015, 51, 6322-6324.

[103] M. K. Coggins, M. T. Zhang, Z. Chen, N. Song, T. J. Meyer, Angew. Chem. Int. Ed., 2014, 53, 12226-12230.

[104] F. Chen, N. Wang, H. Lei, D. Guo, H. Liu, Z. Zhang, W. Zhang, W. Lai, R. Cao, Inorg. Chem., 2017, 56, 13368-13375.

[105] P. Garrido-Barros, I. Funes-Ardoiz, S. Drouet, J. Benet-Buchholz, F. Maseras, A. Llobet, J. Am. Chem. Soc., 2015, 137, 6758-6761.

[106] C. Sens, I. Romero, M. Rodríguez, A. Llobet, T. Parella, J. Benet-Buchholz, J. Am. Chem. Soc., 2004, 126, 7798-7799.

[107] X. Yang, M.-H. Baik, J. Am. Chem. Soc., 2008, 130, 16231-16240.

[108] S. Maji, L. Vigara, F. Cottone, F. Bozoglian, J. Benet-Buchholz, A. Llobet, Angew. Chem. Int. Ed., 2012, 51, 5967-5970.

[109] T. Wada, K. Tsuge, K. Tanaka, Angew. Chem. Int. Ed., 2000, 39, 1479-1482.

[110] T. Wada, K. Tsuge, K. Tanaka, Inorg. Chem., 2001, 40, 329-337.

[111] J. T. Muckerman, D. E. Polyansky, T. Wada, K. Tanaka, E. Fujita, Inorg. Chem., 2008, 47, 1787-1802.

[112] S. Ghosh, M.-H. Baik, Inorg. Chem., 2011, 50, 5946-5957.

[113] S. Ghosh, M. H. Baik, Angew. Chem. Int. Ed., 2012, 51, 1221-1224.

[114] K. Tanaka, H. Isobe, S. Yamanaka, K. Yamaguchi, Proc. Natl. Acad. Sci. USA, 2012, 109, 15600-15605.

[115] T. A. Betley, Q. Wu, T. Van Voorhis, D. G. Nocera, Inorg. Chem., 2008, 47, 1849-1861.

[116] D. J. Wasylenko, C. Ganesamoorthy, B. D. Koivisto, C. P. Berlinguette, Eur. J. Inorg. Chem., 2010, 2010, 3135-3142.

[117] L. Duan, A. Fischer, Y. Xu, L. Sun, J. Am. Chem. Soc., 2009, 131,
10397-10399.

[118] S. Romain, L. Vigara, A. Llobet, Acc. Chem. Res., 2009, 42, 1944-1953.

[119] L. Duan, Y. Xu, M. Gorlov, L. Tong, S. Andersson, L. Sun, Chem.Eur. J, 2010, 16, 4659-4668.

[120] L. Duan, F. Bozoglian, S. Mandal, B. Stewart, T. Privalov, A. Llobet, L. Sun, Nat. Chem., 2012, 4, 418-423.

[121] Y. Xie, D. W. Shaffer, J. J. Concepcion, Inorg. Chem., 2018, 57, 10533-10542.

[122] T. Fan, S. Zhan, M. S. G. Ahlquist, ACS Catal., 2016, 6, 8308-8312.

[123] L. Duan, C. M. Araujo, M. S. G. Ahlquist, L. Sun, Proc. Natl. Acad. Sci. USA, 2012, 109, 15584-15588.

[124] Y. Jiang, F. Li, B. Zhang, X. Li, X. Wang, F. Huang, L. Sun, Angew. Chem. Int. Ed., 2013, 52, 3398-3401.

[125] M. Okamura, M. Kondo, R. Kuga, Y. Kurashige, T. Yanai, S. Hayami, V. K. K. Praneeth, M. Yoshida, K. Yoneda, S. Kawata, S. Masaoka, Nature, 2016, 530, 465-468.

[126] R.-Z. Liao, S. Masaoka, P. E. M. Siegbahn, ACS Catal., 2018, 8, 11671-11678.

[127] S. Neudeck, S. Maji, I. López, S. Meyer, F. Meyer, A. Llobet, J. Am. Chem. Soc., 2014, 136, 24-27.

[128] Z. Deng, H.-W. Tseng, R. Zong, D. Wang, R. Thummel, Inorg. Chem., 2008, 47, 1835-1848.

[129] J. Odrobina, J. Scholz, A. Pannwitz, L. Francàs, S. Dechert, A. Llobet, C. Jooss, F. Meyer, ACS Catal., 2017, 7, 2116-2125.

[130] J. Odrobina, J. Scholz, M. Risch, S. Dechert, C. Jooss, F. Meyer, ACS Catal., 2017, 7, 6235-6244.

[131] T. Nakazono, A. R. Parent, K. Sakai, Chem. Commun., 2013, 49, 6325-6327.

[132] T. Nakazono, A. R. Parent, K. Sakai, Chem.-Eur. J, 2015, 21, 6723-6726.

[133] H. A. Younus, N. Ahmad, A. H. Chughtai, M. Vandichel, M. Busch, K. Van Hecke, M. Yusubov, S. Song, F. Verpoort, ChemSusChem, 2017, 10, 862-875.

[134] Y. Zhao, J. Lin, Y. Liu, B. Ma, Y. Ding, M. Chen, Chem. Commun., 2015, 51, 17309-17312.

[135] B. Das, A. Orthaber, S. Ott, A. Thapper, Chem. Commun., 2015, 51, 13074-13077.

[136] D. J. Wasylenko, C. Ganesamoorthy, J. Borau-Garcia, C. P. Berlinguette, Chem. Commun., 2011, 47, 4249-4251.

[137] S. W. Kohl, L. Weiner, L. Schwartsburd, L. Konstantinovski, L. J. Shimon, Y. Ben-David, M. A. Iron, D. Milstein, Science, 2009, 324, 74-77.

[138] X. Yang, M. B. Hall, J. Am. Chem. Soc., 2010, 132, 120-130.

[139] Y. Chen, W.-H. Fang, J. Phys. Chem. A, 2010, 114, 10334-10338.

[140] T. P. Brewster, J. D. Blakemore, N. D. Schley, C. D. Incarvito, N. Hazari, G. W. Brudvig, R. H. Crabtree, Organometallics, 2011, 30, 965-973.

[141] D. G. H. Hetterscheid, J. N. H. Reek, Chem. Commun., 2011, 47, 2712-2714.

[142] J. Graeupner, U. Hintermair, D. L. Huang, J. M. Thomsen, M. Takase, J. Campos, S. M. Hashmi, M. Elimelech, G. W. Brudvig, R. H. Crabtree, Organometallics, 2013, 32, 5384-5390.

[143] M. Zhang, M. T. Zhang, C. Hou, Z. F. Ke, T. B. Lu, Angew. Chem. Int. Ed., 2014, 53, 13042-13048.

[144] G. Y. Luo, H. H. Huang, J. W. Wang, T. B. Lu, ChemSusChem, 2016, 9, 485-491.

[145] J. W. Wang, X. Q. Zhang, H. H. Huang, T. B. Lu, ChemCatChem, 2016, 8, 3287-3293.

[146] Y. Liu, Y. Han, Z. Zhang, W. Zhang, W. Lai, Y. Wang, R. Cao, Chem. Sci., 2019, 10, 2613-2622.

[147] W.-T. Lee, S. B. Muñoz III, D. A. Dickie, J. M. Smith, Angew. Chem. 
Int. Ed., 2014, 53, 9856-9859.

[148] D. W. Crandell, S. Xu, J. M. Smith, M.-H. Baik, Inorg. Chem., 2017, $56,4435-4445$.

[149] Y. Y. Li, K. Ye, P. E. Siegbahn, R. Z. Liao, ChemSusChem, 2017, 10, 903-911.

[150] X. J. Su, M. Gao, L. Jiao, R. Z. Liao, P. E. Siegbahn, J. P. Cheng, M. T. Zhang, Angew. Chem. Int. Ed., 2015, 54, 4909-4914.
[151] Y. Pushkar, Y. Pineda-Galvan, A. K. Ravari, T. Otroshchenko, D. A. Hartzler, J. Am. Chem. Soc., 2018, 140, 13538-13541.

[152] J. A. Halfen, S. Mahapatra, E. C. Wilkinson, S. Kaderli, V. G. Young, L. Que, A. D. Zuberbühler, W. B. Tolman, Science, 1996, 271, 1397-1400.

[153] S. J. Koepke, K. M. Light, P. E. VanNatta, K. M. Wiley, M. T. Kieber-Emmons, J. Am. Chem. Soc., 2017, 139, 8586-8600.

\title{
分子催化剂催化水氧化过程及其O-O成键机理
}

\author{
张学鹏, 王红艳, 郑浩铨, 张伟, 曹 飸*
}

陕西师范大学化学化工学院, 应用表面与胶体化学教育部重点实验室, 陕西西安710119

摘要: 随着化石燃料的不断消耗和生存环境的日益恶化, 可再生、清洁且环境友好的新能源逐渐受到广泛关注与利用. 太 阳能作为一种洁净的可再生能源, 在自然界中, 植物可以通过光合作用将太阳能转换成化学能. 在该过程中, 水分子在光 系统II中被氧化而释放出氧气, 伴随生成的质子和电子进一步将二氧化碳转化为蕴含生物质能的碳水化合物.

在光系统II中, 叶绿素P 680 被光照激发生成阳离子自由基 $\mathrm{P} 680^{\circ}$, 其具有很强的氧化能力, 可以从附近的析氧中心中夺 取电子. 析氧中心通过这一过程失去 4 个电子, 可以将两分子水氧化生成一分子氧气和 4 个质子. 作为水裂解的半反应之 一, 水氧化在热力学方面需要很多能量来断裂 4 个 $\mathrm{O}-\mathrm{H}$ 键 $(\Delta E=1.23 \mathrm{~V} v \mathrm{~s}$. NHE), 在动力学方面涉及 4 个氢原子与 2 个氧原子 的重组以及氧气的释放, 因而水氧化析氧是一个非常缓慢的过程, 如何高效稳定地催化水氧化一直是人们研究的热点和难 点. 研究发现, 自然界中存在的析氧中心为 $\mathrm{Mn}_{4} \mathrm{CaO}_{x}$ 的钻锰簇合物, 在水氧化过程中生成的 $\mathrm{Mn}=\mathrm{O}$ 物种可以被游离的水分 子亲核进攻形成 $\mathrm{O}-\mathrm{O}$ 键, 也可以与桥连 $\mu-\mathrm{O}(\mathrm{H})$ 反应生成 $\mathrm{O}-\mathrm{O}$ 键. 通过对析氧中心持续的研究, 在过去几十年中设计合成了

一系列具有水氧化催化活性的基于金属配合物的分子催化剂.

分子催化剂催化水氧化一般主要分为金属-氧物种的演化过程以及 $\mathrm{O}-\mathrm{O}$ 成键过程. 通常, 金属-氧物种可以通过失电子 或质子耦合的失电子过程逐步生成高价态的金属-氧物种, 其引发的 $\mathrm{O}-\mathrm{O}$ 成键过程通常是水氧化催化循环的决速步骤. 基 于之前的研究成果, 目前主要报道了五种不同的O-O成键机理: (1)水亲核进攻金属-氧物种的WNA机理, (2)金属-氧自由基 耦合的I2M机理, (3)金属-羟基自由基耦合的HC机理, (4)分子内进攻桥连氧的IOC机理以及(5)氧化还原异构的RI机理.

本文综述了过去几十年水氧化分子催化剂的发展, 总结了贵金属钓和铱配合物到第一过渡金属锰、铁、钴、镍和铜配 合物催化水氧化过程中金属-氧物种的生成与演化, 重点阐述了引发 $\mathrm{O}-\mathrm{O}$ 成键过程的高价态金属-氧物种的种类及其不同的 O-O成键机理. 重点总结了 O-O成键中WNA机理与I2M机理的异同, 并阐述了催化剂设计对WNA与I2M机理选择性的影 响. 通过对金属-氧物种种类和 $\mathrm{O}-\mathrm{O}$ 成键机理的总结, 将有助于进一步设计合成高效稳定的水氧化分子催化剂.

关键词: 产氧反应; 水氧化; $\mathrm{O}-\mathrm{O}$ 成键; 过渡金属配合物; 分子电催化; 反应机理

收稿日期: 2020-08-11. 接受日期: 2020-09-22. 上网时间: 2021-04-05.

*通讯联系人. 电子信箱: ruicao@snnu.edu.cn

基金来源：国家自然科学基金(21101170, 21573139, 21773146); 霍英东青年教师基金; 中央高校基本科研基金; 陕西师范大学研 究经费.

本文的电子版全文由Elsevier出版社在ScienceDirect上出版(http://www.sciencedirect.com/journal/chinese-journal-of-catalysis). 